\title{
DO USO Á NORMA, DA NORMA AO USO (VARIACIÓN SOCIOLINGÜÍSTICA E ESTANDARIZACIÓN NO IDIOMA GALEGO)
}

\author{
Henrique Monteagudo
}

Instituto da Lingua Galega (USC)

Unha comunidade arredor de calquera tipo de normas — lingüísticas, éticas, relixiosas ou legais - non cae do ceo tal cal, nin se alicerza nunha harmonía preestablecida universalmente implantada: máis ben é produto e resultado inestable do traballo ou coordinación permanentes no tocante á creación e preservación das normas que a definen como comunidade, sexa lingüística ou doutro tipo. No seu seo, algúns senten máis responsabilidade ca outros, e mesmo adoita crearse un nutrido grupo de membros dela que son designados e remunerados pola comunidade para se dedicaren precisamente a mantela. [...] O cultivo da lingua é, pois, un labor necesario para crear e preservar a comunidade lingüística, e as persoas que se preocupan do que é correcto ou incorrecto participan nesta tarefa velando polo cumprimento das normas comúns que definen a comunidade como un grupo de persoas que se entenden mutuamente ata o punto de seren capaces de interpretar o comportamento (lingüístico) como unha acción (lingüística) mediante esas normas comúns, é dicir, mediante expectativas comúns e expectativas de expectativas que non deben ser contrariadas. O feito de que normas secundarias sexan ás veces obxecto dun exceso de atención non debe utilizarse como argumento para desacreditar na súa totalidade a idea principal e a propia empresa do cultivo da lingua, na cal colabora a comunidade lingüística en todo o seu conxunto.

(Renate Bartsch)

Recentemente dei ao prelo un traballo de longo alento sobre o proceso de estandarización do idioma galego. Fora o meu propósito revisar nel, a partir dunha perspectiva histórica, os aspectos máis problemáticos da cuestión abordada e os debates movidos á súa volta. Nese traballo contéñense observacións que, coido, aquecerían á presente ocasión, pero que sería escusado repetir aquí1. No contributo que abren estas liñas teño mentes de de-

1 Véxase Monteagudo 2003, especialmente pp. 44-46 e 113-20. 
senvolver nunha reflexión de horizontes máis teóricos sobre a variación lingüistica, que se quere ofrecer como un convite a unha pescuda de enorme interese e de importancia difícil de esaxerar no ámbito galego pero aínda case totalmente inédita nos nosos pagos $^{2}$; cunha coda en defensa dun prescritivismo racionalmente motivado, en polémica máis ou menos aberta tanto coas posicións esencialistas (sexan nativistas ou ultrapuristas) canto coas laxistas.

Na primeira sección do traballo, atinxente á variación lingüística, procurei aclarar perspectivas e afinar conceptos nun terreo dabondo complexo e esvaradío ata o extremo. Coido que a tentativa pagou a pena, aínda que son consciente de que cómpre decruar moito máis o terreo; en todo caso, é difícil avanzar sen o esteo dunha investigación empírica da que carecemos case totalmente (carencia esta pola que asumo a alícuota parte da responsabilidade). A segunda sección, centrada na prescrición, benefíciase dun labor previo dabondo intenso, ao que hai que engadir a recente descuberta persoal dunha sociolingüística brasileira que está a xurdir con admirable pulo, e coa que coido imperativo que trabemos diálogo intelectual. Así e todo, para afondar neste aspecto cumpriría contar cun vagar que hoxe por hoxe me é imposible conseguir, malia os xenerosos sacrificios dalgunhas das persoas máis próximas, que quero agradecer de todo corazón.

Nos últimos vinte anos téñense realizado en Galicia unha nutrida serie de inquéritos de campo que permiten facérmonos unha imaxe aproximada da situación sociolingüística do noso país ${ }^{3}$. Esta imaxe adoita formularse en termos da distribución desigual do coñecemento e uso do galego e o castelán a través de distintos sectores da sociedade galega. Os parámetros que mellor dan conta desa distribución socialmente condicionada teñen que ver dunha banda cunha serie de contextos de uso (en función do interlocutor, dos dominios de uso/xéneros comunicativos ou do soporte oral/ escrito do texto) e doutra banda coa identidade social dos falantes, establecida en termos de estatus (clase social, ingresos, categoría profesional, nivel de estudos e hábitat de nacemento ou residencia parecen ser os factores máis importantes), de xénero/ sexo e mais idade. Nestes traballos, 'galego' e 'castelán' aparecen como variables independentes, ou, por dicilo doutro xeito, como categorías invariantes, non sometidas a escrutinio. Pero, a pouco coñecemento que se posúa da realidade lingüística galega, aínda que sexa puramente empírico e non reflexivo, sabemos que, por caso, o galego e o castelán que 'sa-

2 Salvo, claro está, o impresionante desenvolvemento dos estudos dialectolóxicos, dun valor inestimable e en pleno proceso de renovación, pero que non esgotan o tema.

3 Véxase por exemplo a bibliografía elencada en Monteagudo 2002: 26-28. 
be'/'usa' unha rapaza de clase media que vive no centro dunha cidade (poñamos Vigo ou A Coruña) non son os mesmos galego ou castelán que 'sabe'/usa' ou seu curmán que mora na aldea, e menos aínda os dun seu tío emigrante en Suíza ou da súa avoa campesiña.

No presente traballo, cando falamos de 'variación sociolingüística' o que imos problematizar é precisamente esta vertente da cuestión: o que agora funcionarán como variables independentes serán as categorías sociais/funcionais, mentres que a lingua (en concreto, o galego), constituirá a variable dependente, sometida á pescuda. En sociolingüística, o enfoque descrito no parágrafo anterior denomínase 'socioloxía da lingua', o que imos emprender aquí denominámolo 'sociolingüística (estrita)'. Seicasí, no caso da nosa situación, fronte á relativa abundancia de traballos de socioloxía da lingua (doadamente explicable pola urxencia de establecer un diagnóstico sobre a situación do galego que sirva de base a unha política lingüística eficaz), atopámonos cunha notable carestía de investigacións 'estritamente' sociolingüísticas. Isto condicionará, como é lóxico, a orientación e o horizonte do noso percurso.

O que vén a seguir pode lerse como prolegómeno ao traballo sobre a estandarización lingüística que citei ao comezo, unha especie de exploración dos presupostos que lle subxacen. Constitúe, tamén, unha reflexión preliminar sobre o tema proposto no Simposio onde se presentou; por tanto, debe entenderse como un limiar ao conxunto do volume que o contén, aínda que veña colocado ao remate deste. Será cousa, logo, de tornarmos no futuro sobre os temas aquí apuntados, equipados xa dunha investigación de campo máis densa e mellor alicerzada.

\section{DO USO Á NORMA}

Entre as ideas máis importantes que a sociolingüística veu confirmar, afinar e desenvolver no tocante aos estudos da linguaxe atópanse estas dúas: (a) as linguas constitúen sistemas abertos, heteroxéneos e dinámicos, mellor definibles como sistemas de sistemas (polisistemas); ráchase así coa tradicional visión das linguas como entidades discretas e homoxéneas, estruturas ríxidas, estáticas e pechadas; (b) as características de abertura e heteroxeneidade dos sistemas lingüísticos non constitúen un empeitizo para o funcionamento das linguas na comunicación, pola contra, responden ao carácter interconexo e internamente diversificado das comunidades de falantes. Imponse pois un paradigma de coñecemento que incorpore a complexidade real dos sistemas lingüísticos como un elemento central. 
Gaetano Berruto pregúntase polas raíces profundas do fenómeno da variación lingüística e apunta que esta é unha característica inherente que responde a dúas necesidades innatas da especie humana, a diferenciación e a identificación:

A variación lingüística, cos seus matices que se engaden ao valores comunicativos referenciais do código lingua, permiten ao instrumento lingua responder da maneira máis flexible e funcional ás esixencias cada vez máis diversificadas e complexas da vida, da estrutura e das relacións sociais. Ao tempo, a variación lingüistica pode ser empregada, conferíndolle determinados valores simbólicos, como un importante medio e vehículo de información, afirmación e transmisión da identidade sociocultural e incluso persoal (Berruto 2004: 89).

Por outras palabras, a heteroxeneidade interna dos sistemas lingüísticos é funcional, a homoxeneidade é o que resultaría disfuncional (Lucchesi 2002: 66-67). Nese senso, despois de denunciar a natureza "mitolóxica" do suposto carácter discreto (discreteness) dos sistemas lingüísticos, Robert LePage sinala que o que esixe unha explicación non é o fenómeno da variación lingüística, mais en todo caso a formación do concepto dunha lingua homoxénea; consecuentemente, este autor propón abandonar a noción estereotipada de lingua ${ }^{4}$.

O estudoso devandito analiza a influencia que as tradicións gramaticais acostuman ter no proceso de construción dunha 'lingua': pártese da observación do discurso, continúase pola acuñación de estereotipos do tipo 'lingua $\mathrm{X}^{\prime}$ aos que son asignados determinados textos (entendendo por texto calquera produto verbal minimamente congruente), e vaise elaborando un modelo gramatical cada vez máis abstracto e focalizado de tal lingua $\mathrm{X}$, que, convenientemente difundido, imposto e recoñecido, informa unhas prácticas lingüísticas que son presentadas como referencia exemplar. No proceso, conforme a lingua X é progresivamente nomeada, formalizada, estandarizada, institucionalizada e totemizada, tanto o comportamento lingüístico real coma a percepción e a conceptualización deste vai experimentando sucesivos reaxustes, de maneira que se avanza desde un estadio inicial de extrema

4 Véxase LePage 1989 e 1997: 26 e 30-31. Nunha vea similar, na presentación da súa obra Bilingualism (1989), Suzanne Romaine reflexionaba sobre o título do libro, semellante ao doutros moitos estudos sobre o mesmo fenómeno, chamando a atención sobre a estrañeza que produciría un volume que se titulase Monolingüismo. O suposto subxacente é que o bilingüismo é anómalo, mentres que o monolingüismo representa a situación normal. Por certo, Romaine chega a afirmar o seguinte: "the notion of a language is very much an European artifact". Unha afirmación coa que concordamos plenamente (véxase Monteagudo 1997). 
difusividade cara a unha focalización crecentemente máis intensa. Velaí en funcionamento o que o autor denomina 'a lóxica dos sistemas pechados', en que se inscribe a circularidade do proceso de descrición-prescrición gramatical (LePage / Tabouret-Keller 1985: 180-206).

Un, que comezou a falar, escribir e a estudar o galego antes de que se desen os pasos decisivos cara á estandarización, que despois asistiu á xestación das primeiras Normas ortográficas e morfolóxicas do idioma galego oficiais (1982) e que logo foi co-autor dunha Gramática galega que veu a lume hai case vinte anos (1986), pode dar testemuña de como a primeira obra (un código prescritivo) e mais a segunda (un manual pretensamente descritivo) contribuíron a focalizar tanto a imaxe canto o uso do idioma galego, limitando a variación nos textos escritos e en certo senso tamén nos orais (de contado matizaremos isto). Destarte, falando en termos xerais, a Gramática describe mellor o galego actual (cando menos, a súa variedade estándar) ca o galego que se usaba daquela: describindo e codificando un modelo de lingua que entón tiña unha existencia pouco menos que virtual, contribuímos a facelo real, sen sermos totalmente conscientes disto.

\section{O AXIOMA DO RELATIVISMO SOCIOLINGÜÍSTICO E O DILEMA ESTRUTURA/ACCIÓN}

"A sociolingüística pola súa natureza está moi vencellada a un/ha específico/a e particular país/sociedade/comunidade e ás diferenzas entre eles/as, de maneira que o contido tanto dos seus conceptos canto das súas unidades de análise fundamentais é sensible ás especifidades que a informan nunha determinada situación socio-cultural, así que pode variar (mesmo moito) de sociedade a sociedade, de cultura a cultura, de tradición a tradición”. Así define Berruto (1995: 64) o que el denomina 'axioma do relativismo lingüístico', que como acabamos de ver, afecta á mesma noción de 'lingua', non menos cá de "dialecto"s. As análises neste terreo adoitan estar fortemente

5 Véxase a nota anterior polo atinxe á noción de 'lingua'. Canto á de 'dialecto', xusto é a que escolle Berruto como exemplo do relativismo lingüístico. En efecto, son notablemente distintas as maneiras de entender o termo 'dialecto' nas tradicións lingüísticas anglófona, francófona e hispanófona. Canto á tradición anglófona, referirémonos a isto máis adiante (véxase ademais Hudson 1996: 31). Verbo da francófona, son ilustrativas as observacións de Jollin-Bertocchi (2003: 28): "La variation régionale et la diversité dialectale sont deux choses distinctes: sur un même territoire national coexistent souvent plusieurs langues bien differenciées, appelées dialectes pour marquer leur statut de langues dominées sur le plan socioculturel, et généralement exclues de l'enseignement de base". Unha visión teórica da noción de 'dialecto'atópase no artigo xa citado de E. Coseriu (1981b), que fai mención indirecta ao problema do relativismo lingüístico, sen se deter nel. 
condicionados pola propia realidade sociolingüística de cada sociedade, pola cultura lingüística correspondente (Schiffman 1996) e pola tradición académica de que parte cada estudoso. É así que todos os estudos sobre variación lingüística son contextualmente (isto é, culturalmente) dependentes, e sono nun grao moi elevado, polo que hai que ter moita conta de non aplicar mecanicamente á específica situación do galego esquemas derivados da análise doutras dadas situacións.

Velaquí un corolario do devandito axioma que nos atinxe especialmente: o primeiro problema que se presenta á hora de aplicar ao estudo da lingua galega o que podemos denominar 'paradigma variacionista', é que este foi construído (igual que os paradigmas 'invariacionistas' que o precederon) a partir do estudo de linguas 'normais', de locutores monolingües e de comunidades lingüísticas 'normalizadas'. Nesas condicións, por caso, a distinción entre variación 'intersistémica' e variación 'intrasistémica' parece evidente; pola contra, nunha situación de contacto lingüístico coma a nosa, está lonxe de selo, pois ambos os tipos de variación se atopan fitamente entrefebrados, ata o punto de que non hai xeito de distinguir nidiamente un do outro. Non por casualidade, anteriores tentativas de analizar a variación sociolingüística en Galicia atenderon fundamentalmente á variación interlingüística, como despois mostraremos ${ }^{7}$. Á hora de abordar o asunto da variación, non podemos perder de vista de a situación de contacto lingüístico galego/ castelán, máis en concreto, do marco de diglosia composta, ao tempo social e funcional, en que o castelán ocupa nunha posición dominante e o galego subordinada ${ }^{8}$.

Por outra banda, non é menos certo que estamos asistindo ao momento decisivo, á fase final, do proceso de constitución dun sistema lingüístico galego autónomo, que dura xa século e medio, e que se atopa en relación simbiótica coa dinámica de formación dunha identidade galega colectiva. Un proceso que basicamente consistiu nunha pugna por arrincar o galego do continuum interlectal diglósico galego-castelán, a forza de marcar distancias con idioma dominante. Canto a isto, Ferguson sinala que os conxuntos de

6 Véxase Milroy / Milroy 1997: 50-5. Con linguas 'normais' e comunidades 'normalizadas' referímonos a linguas plenamente estandarizadas e solidamente establecidas na respectiva sociedade: linguas estato-nacionais de países (oficialmente) monolingües, conforme o modelo euro-occidental.

7 Véxase Cáccamo 1989: 278-88; Monteagudo / Santamarina 1993: 144-51; e Dubert 2002, a pesar das diferenzas noutros aspectos dos respectivos traballos. Aproveitamos para deixar aquí constancia de que o segundo artigo, aínda que publicado en 1993, foi redactado e entregado para a súa publicación en 1989.

8 Para a distinción 'diglosia social'/ 'diglosia funcional' véxase Monteagudo 1998: 42-45. 
trazos que identifican as variedades lingüísticas varían grandemente no grao de cohesión que mostran como sistemas e no grao de nitidez das fronteiras entre variedades que delimitan, pero que "canto máis cohesionados se achan os sistemas, tanto máis nidias son as fronteiras; e canto máis son estes percibidos polos participantes como entidades separadas, tanto máis útil e analizalos como variedades lingüísticas" (1994: 23). Un dos efectos, non colateral nin imprevisto, mais principal e deliberado (aínda máis, afincadamente procurado, cando menos polos seus promotores) do proceso de estandarización, xustamente derivado da función identificadora do estándar, consiste na súa contribución á 'marcaxe de fronteiras' entre o galego e o castelán?.

Esta última observación condúcenos a outro aspecto da especifidade da situación do idioma galego que resulta incontornable cando abordamos o asunto que nos ocupa. O proceso de estandarización do galego só moi recentemente gañou pulo e se deu encarreirado de maneira decidida. Hoxe mesmo, malia os importantes progresos conseguidos nas tres últimas décadas, tal proceso está lonxe da súa culminación -meta esta que, sobexo resulta lembralo, está vencellada a unha normalización social de consecución incerta. En troca, acontece que na maior parte dos traballos de referencia sobre a variación sociolingüística (poñamos por caso os realizados nos ámbitos italiano, francés ou anglonorteamericano) a vixencia do estándar non só constitúe un dado de partida incuestionable, mais unha referencia central (mesmo, se como acontece en Italia, a estandarización da comunidade lingüística non está completada realizada).

Isto último explícase pola boa razón de que a variedade estándar constitúe o eixo da arquitectura da lingua, o seu principio organizador, aspecto no que nos deteremos máis adiante. Non é que a estandarización redunde nunha redución global da variación lingüística, como ás veces equivocadamente se supón. É innegable que a estandarización implica un certo grao de uniformización da lingua (mediante a fixación, codificación e difusión dunha variedade-modelo) e de homoxeneización da comunidade falante (isto é,

9 Xa os teóricos de Praga apuntaban á función identificadora (isto é, internamente unificadora e externamente separadora) da variedade estándar (véxase Monteagudo 1994), unha función de relevancia difícil de esaxerar no marco da dinámica simbiótica a que nos referemos antes. No caso galego as posicións historicamente variaron (e varían) canto á importancia outorgada á función 'separadora' e ao grao de distancia con respecto ao castelán que se considera óptimo. Así tanto os ultra-enxebristas coma os reintegracionistas colocan o listón moito máis lonxe cá 'corrente central' rexeneracionista. Con todo, resulta claramente abusiva a acusación de que as Normas oficiais tenden cara a (ou mesmo procuran) a dialectalización do galego. Outra cousa é que algúns dos sectores máis conscientes da galegofonía estimen que a distancia que aquelas 'marcan' con respecto ao castelán resulte curta ou insuficiente (véxase sobre isto Monteagudo 2003: 90-92). 
aceptación, aprendizaxe e adopción efectiva desta variedade polos utentes), pero tamén implica diversificación así lingüística coma socio-funcional, que se traduce na ampliación do abano de estilos (en particular da súa 'franxa alta', a correlativa aos contextos formais), coa xeración de novos rexistros funcionais (as variedades especializadas) e o correspondente incremento de recursos idiomáticos, uns e outros ao dispor de novos utentes en ocasións de uso moitas veces inéditas ${ }^{10}$. A diferenza entre unha lingua/ comunidade estandarizada e outra que non o está radica, pois, non na 'cantidade' global de variación sociolingüística (supostamente menor na primeira ca na segunda) mais no carácter e organización desa variación, coa redución ou eliminación da redundante segundo un criterio socio-funcional e o incremento metódico e controlado (polo menos en parte) da variación pertinente, convenientemente distribuída e arrombada, segundo o mesmo criterio

A consideración do proceso de estandarización, unha manifestación especial do fenómeno máis xeral que demos en denominar 'elaboración da lingua', suxírenos a necesidade de distinguir entre variantes/variedades vernáculas e cultivadas. As primeiras serían nativas, as transmitidas e adquiridas pola xeneralidade dos falantes mediante socialización primaria; as segundas, as elaboradas, serían as transmitidas e aprendidas mediante socialización secundaria. A distinción, con todo, non é tallante nin necesariamente permanente, pois unha variedade vernácula poder ser obxecto de cultivo (ata, se é o caso, tornarse na base dun estándar), mentres que as variedades cultivadas poden vernacularizarse, cando menos parcialmente. Volveremos sobre esta cuestión.

Pasamos agora a outra cuestión previa ao presente traballo. No estudo sociolingüístico da variación lingüística desenvolvéronse dúas estratexias de investigación que responden a cadansúa perspectiva: a variacionista ou correlacional e a interaccional ou interpretativa. A primeira contempla a cuestión desde o punto de vista do observador externo que se sitúa no nivel das estruturas sociais (o nivel 'macro'), neste caso das estruturas sociolingüísticas que condicionan o comportamento dos falantes; por tanto as súas nocións centrais son do tipo de 'comunidade lingüística', 'lingua' ou 'variedade'. A segunda colócase na perspectiva dos axentes en contextos reais de actuación (nivel 'micro') e do sentido que estes dan ás accións (súas e dos outros 'actores'), neste caso dos locutores que nas súas interaccións manexan un

\footnotetext{
${ }^{10}$ Referímonos a neofalantes absolutos, pero tamén neousuarios relativos, por caso, falantes nativos dunha variedade vernácula que antes eran blingües/ diglósicos e agora utilizan a variedade estándar na lectoescritura, no ámbito profesional, no dominio público.
} 
determinado repertorio lingüístico; xa que logo as súas nocións centrais son do tipo 'discurso', 'texto' ou 'variante'11. Sabido é que debaixo da diverxencia entre estas dúas orientacións (que podemos designar como 'lingua/ discurso') latexan problemas de grande alcance na teoría sociolóxica (o dilema punto de vista da estrutura/ dos axentes; a dicotomía nivel macro-/ nivel micro- da análise), que, por razóns obvias, non aspiramos a debullar neste lugar. Coidamos que no fondo constitúen enfoques complementarios, emporiso, sen perder de vista a segunda perspectiva, imos privilexiar a primeira, no convencemento de que é a fundamental e, ademais, no noso caso resulta prioritaria. Espero que ao longo das liñas que seguen queden máis ou menos claros os argumentos en que descansa esta nosa convición.

\section{OS EIXOS OU PARÁMETROS DE VARIACIÓN}

O fenómeno da variación maniféstase na existencia de variables, isto é, de unidades de calquera plano do sistema gramatical (fónico, morfolóxico, sintáctico,...) que presentan realizacións diferentes ${ }^{12}$. Cada unha desas posibles realizacións representa unha variante. Xa que logo, unha variante é un elemento lingüístico que se atopa en concorrencia con outro ou outros, representando cada un deles realizacións alternativas dunha mesma unidade; o conxunto das variantes constitúe tal unidade (a variable). Existen variantes analizables en termos gramaticais, coma tal, varias realizacións dun fonema condicionadas polo contexto fonético (caso dos alófonos [b] e [ $\beta]$ do fonema /b/). En troques, no caso doutras variantes, a aparición dunha ou outra non depende de (ou correlaciona con) factores lingüistico-estruturais, mais de factores sociais ou comunicativo-funcionais, como pode ser a identidade do falante (procedencia xeográfica, estatus sociocultural, sexo ou grupo de idade...) ou ben a situación de uso da lingua ou o tipo de texto en que aparece (formal/ informal, escrita/ falada, poema/ manual de instrucións...).

O segundo tipo de variantes constitúen as variantes sociolingüísticas, que son as que nos van interesar aquí. Por vía de exemplo: os fonos $[\mathrm{g}] /[\mathrm{h}] /[\mathrm{x}]$ na pronuncia da consoante inicial de gato; os finais -an/ -ao / -au nos nomes do tipo chan / chao / chau; as formas dereito/direito /dreito, poblema/ problema, estar/tar; pa / pra / para; os plurais -ns/ -s / -is en nomes como ra-

${ }^{11}$ Esta liña de investigación está representada en Galicia por C. Álvarez Cáccamo, que se especializou no estudo dun fenómeno, a alternancia de códigos ('code-switching') que non imos tocar aquí; véxase por caso Álvarez Cáccamo 1998 e a súa propia bibliografía aí citada.

${ }^{12}$ Empregamos 'gramatical' nunha acepción lata, que inclúe tamén os estratos semántico, informativo e pragmático. 
zóns / razós / razois; a orde dos clíticos en sintagmas como váiseche / váichese; as variacións morfosintácticas, léxico-semánticas ou pragmáticas en enunciados como non che vin / non te vin / non te mirei / non te mirin; non cheirei de por onde me viña aquel ghicho / non me dei de conta de que me quería aquel tipo / non me decatei das intencións daquel individuo; permíteme acceder, cabaleiro? / podo entrar, amigo? / paso que arraso, meu!

Coas variables sociolingüísticas relaciónase a noción de variedade, que podemos definir como un (sub)sistema congruente de variantes, cunha distribución análoga nun determinado parámetro -coma tal: 'a fala de Fisterra', 'a linguaxe da poesía de Curros Enríquez', 'a xerga dos canteiros', 'o falar xuvenil' ou 'o galego común'13. Moitos autores empregan o termo lecto como sinónimo de 'variedade', e outros utilizan, dun xeito máis ou menos sistemático, dialecto como sinónimo de ambas as dúas designacións. Endebén, o termo 'variedade' cobre un espectro semántico considerablemente máis amplo ca 'lecto': o primeiro pode ser coextensivo con 'lingua' pero pode referirse a un falar local e mesmo a un treito de fala, mentres que o segundo se aplica máis ben ás variedades de que imos falar no presente artigo, isto é, (sub)sistemas lingüísticos que ocupan unha posición intermedia entre as linguas e os falares individuais (os idiolectos). Por parte, 'dialecto' presenta o problema da súa ambigüidade, polo que é preferible limitar o seu uso ás variedades diatópicas.

É sabido que xa a lingüística estrutural funcional, cando menos algúns dos seus representantes máis cualificados, se tiña achegado con tino á cuestión da variación sociolingüística intrasistemática. Así, seguindo a coñecida proposta de Eugenio Coseriu (1981a: 302-7, e 1981b: 1-3 e 12-17), debemos distinguir variantes / variedades diacrónicas e sincrónicas. O criterio para identificar as primeiras é de tipo cronolóxico: trátase de variantes / variedades distribuídas ao longo do eixo temporal. Entre as segundas, que son as que nos interesarán aquí, este lingüista distingue os seguintes eixos ou parámetros de variación:

O eixo espacial, xeográfico ou territorial: variantes e variedades diatópicas. O eixo social ou de estrato sociocultural: variantes e variedades diastráticas. O eixo da modalidade expresiva: variantes e variedades diafásicas.

As variedades correspondentes a estes tres parámetros son denominadas por Coseriu segundo unha terminoloxía bastante corrente: a) dialectos, b) niveis, e c) estilos ou rexistros. O mesmo estudoso advirte que cada un dos

\footnotetext{
${ }^{13}$ Desde o punto de vista sociolingüístico, Hudson define a variedade como "conxunto de elementos lingüísticos cunha distribución social similar" (Hudson 1996: 22). Teriamos que alargar moito o alcance do 'social' para que esta definición fose dabondo abranxente.
} 
(sub)sistemas lingüísticos delimitados segundo os criterios devanditos é homoxéneo só desde un punto de vista: en cada dialecto poden comprobarse diferenzas diastráticas e diafásicas (e por tanto, niveis e estilos de lingua) e en cada nivel, diferenzas diatópicas e estilísticas, e en cada estilo, diferenzas diatópicas e diastráticas. Por parte, os límites entre os niveis e os estilos de lingua poden ser diversos nos distintos dialectos; e os límites entre os estilos tamén poden ser diversos nos distintos niveis. Axiña volveremos sobre isto. A caracterización en cada plano da lingua (fónico, morfolóxico, sintáctico, ...) das variedades identificables nas distintas dimensións sinaladas, o estudo das relacións mutuas entre estas e análise da posición relativa que ocupan no sistema lingüístico permiten deseñar o que se deu en denominar a 'arquitectura' dunha lingua histórica, isto é, a configuración ou articulación interna do correspondente diasistema (Coseriu 1981b: 21-22; Berruto 2004: 91) ${ }^{14}$.

Canto ao eixo espacial, Coseriu sinala que as diferenzas diatópicas son evidentes en moitos idiomas ao nivel da 'lingua popular', pero tamén existen ao nivel da 'lingua común' no plano rexional (variedades rexionais), e nas linguas de gran difusión ao nivel da 'lingua común e literaria' no plano internacional (variedades nacionais, propias de países politicamente independentes e culturalmente autónomos). No tocante ás diferenzas entre os estratos socioculturais da comunidade lingüística, o autor advirte que se refire a aquelas que non coinciden coas diferenzas diatópicas (as que existen entre 'lingua común' e os 'dialectos'): así, por caso, o 'italiano popular' sería catalogado como modalidade diastrática do 'italiano común'. Finalmente, verbo das diferenzas canto á modalidade expresiva, Coseriu refírese explicitamente ás que opoñen a lingua falada e a lingua escrita, o modo de falar familiar fronte ao público (ou o solemne), a linguaxe corrente e a burocrática, ou os distintos xéneros literarios. Tamén considera dentro deste eixo de variación as diferenzas que caracterizan distintos grupos biolóxicos (varóns/ mulleres, nenos/ mozos/....) no interior do mesmo estrato sociocultural.

Dado o amplo recoñecemento con que conta, a devandita proposta pódenos servir de soleira e de fío condutor para a reflexión sobre o asunto que nos ocupa. Así e todo, apuntariamos á partida algunhas matizacións e observacións críticas con carácter xeral. En primeiro lugar -e tal como sinalamos anteriormente, moi importante para nós-, nas situacións de contacto entre linguas é imprescindible ter en conta que adoito a variación intrasistémica é inseparable da variación intersistémica (que poderiamos denominar diaglósi-

\footnotetext{
${ }^{14}$ Nós preferimos empregar o termo 'polisistema' no canto de 'diasistema', por razóns que explicamos noutro lugar (Monteagudo 1997).
} 
ca), resultante das influencias recíprocas e a mutua interpenetración entre as linguas en contacto. Consecuentemente, podemos falar de variantes e variedades interlectais (as segundas é corrente denominalas 'interlectos'). En segundo lugar, a sociolingüística cuestiona radicalmente a dicotomía diacronía/ sincronía, pois o estudo da variación permite contemplar o fenónemo do cambio lingüístico como un proceso, non, tal como o contempla a lingüistica histórica tradicional, como un resultado. De toda maneira, non imos desenvolver aquí esta última observación.

Pola contra, interésanos máis problematizar a distinción entre a variación diatópica e a diastrática, na liña da tradición lingüística anglófona, que trata conxuntamente ambos fenómenos baixo a etiqueta de 'dialecto' (lembremos de novo o axioma do relativismo lingüístico). Así, Halliday, na súa proposta de clasificación da variación lingüística define conxuntamente a variación socio-dialectal, e opona á socio-funcional, segundo o seguinte esquema (que presentamos en forma adaptada e simplificada):

\begin{tabular}{|c|c|}
\hline Variación socio-dialectal & Variación socio-funcional \\
\hline Dialectos (xeo-sociais) & Rexistros/ estilos \\
\hline$=$ Variables dependentes do usuario & $=$ Variables dependentes do uso \\
\hline $\begin{array}{l}\text { - Un sociodialecto é: } \\
\text { - o que un fala habitualmente } \\
\text { - determinado por quen é } \\
\text { (grupo social/rexión de orixe ou adopción) } \\
\text { - expresa diversidade da estrutura social } \\
\text { (pautas de xerarquía social) }\end{array}$ & $\begin{array}{l}\text { - Un estilo é: } \\
\text { - o que un fala nunha situación dada } \\
\text { - determinado polo que está a facer } \\
\text { (natureza da actividade social en curso) } \\
\text { - expresa diversidade de procesos sociais } \\
\text { (división social do traballo) }\end{array}$ \\
\hline $\begin{array}{l}\text { - Os sociodialectos son maneiras } \\
\text { distintas de dicir o mesmo e tenden a } \\
\text { diferenciarse en fonética/fonoloxía, } \\
\text { gramática e léxico }\end{array}$ & $\begin{array}{l}\text { - Os estilos son maneiras } \\
\text { dicir cousas diferentes, e tenden a } \\
\text { diferenciarse na semántica (e por tanto en } \\
\text { léxico e gramática, e ás veces en fonoloxía). }\end{array}$ \\
\hline •Exemplos típicos: & •Exemplos típicos: \\
\hline Variedades subculturais (subestándar) & Linguaxes de especialidade (tecnolectos) \\
\hline -Principais variables de control: & -Principais variables de control: \\
\hline $\begin{array}{l}\text { Clase social, hábitat (rural/ urbano), } \\
\text { xeración/ idade, xénero }\end{array}$ & $\begin{array}{l}\text { Campo (tipo de acción social), teor } \\
\text { (relacións de rol), modo (organización simbólica) }\end{array}$ \\
\hline -Caracterízanse por: & •Caracterízanse por: \\
\hline $\begin{array}{l}\text { Fortes actitudes cara a eles como símbolo } \\
\text { de diversidade social }\end{array}$ & $\begin{array}{l}\text { Distincións importantes fala/escrita; lingua } \\
\text { en acción/ lingua en reflexión }\end{array}$ \\
\hline
\end{tabular}

Táboa 1.- Diferenzas sociolecto-dialecto versus estilo/rexistro. Adaptado de Halliday (1978: 35). 
A proposta de Halliday seméllanos máis fundamental cá de Coseriu, aínda que non necesariamente incompatible con esta. Segundo ela, a variación lingüística (sincrónica) organízase segundo dous parámetros fundamentais: a identidade social do falante e os contextos de uso da lingua. A primeira determina a variedade 'básica' do locutor, os segundos condicionan o rexistro utilizado segundo as ocasións. Para este autor, o sociodialecto (el fala de 'dialect') "non é asunto de escolla" e "acompáñanos toda a vida" (Halliday 1978: 33$)^{15}$.

Tampouco Trudgill, un especialista británico no que el mesmo denomina Xeolingüística (unha disciplina que pretente aliar a dialectoloxía tradicional coa sociolingüística), non distingue tallantemente entre o que adoitamos denominar dialectos (xeográficos) e sociolectos. Unha razón disto pode ser, como el mesmo sinala, que a variación rexional (xeográfica) acostuma ser moito máis marcada entre os falantes das clases populares e de baixo nivel educativo do que entre os de clases medias e altas 'educadas' (véxase figura $\left.n^{\circ} 1\right)^{16}$. Canto máis se baixa na escala social, maiores son as diferenzas fónicas, gramaticais e léxicas entre as variedades territoriais e con respecto á variedade común ${ }^{17}$; o maior nivel de variación rexional atópase nos dialectos rurais, particularmente os falados polas persoas maiores con baixo nivel educativo. O gráfico enfatiza a natureza continua (non discreta) da variación lingüística, aspecto este de que nos ocuparemos axiña: "resulta aínda menos axeitado falar de dialectos sociais discretos do que de dialectos rexionais discretos, dado que as variedades se funden unha na outra, e as diferenzas entre elas baséanse na frecuencia de ocorrencia de variantes particulares máis que na presenza ou ausencia destas" (Trudgill 1983: 187). Por parte, como veremos, os dialectos territoriais defínense por un abano de variables máis amplo (canto ao número e canto aos niveis de lingua atinxidos) do que os sociolectos.

${ }^{15}$ Aínda que a sociedade actual, coa mobilidade social e xeográfica que a caracteriza, dá a moitos falantes a oportunidade de (ou obrígaos a) aprender e usar dous ou máis sociodialectos, sucesiva ou coordinadamente. No segundo caso, alternará o uso deles dependendo do contexto de situación -deste xeito, os sociodialectos poden tornarse un aspecto do rexistro. Por outra banda, débese ter en conta que a variación relacionada coa idade ou o grupo xeracional introduce trazos lingüísticos 'transitorios' (isto é, que os individuos adoptan nunha etapa determinada da súa vida, pero que despois abandonan) que caracterizan os distintos grupos etarios, especialmente a infancia e a mocidade.

${ }^{16}$ Véxase Trudgill 1974: 41 e 1983: 186-88.

17 O autor fala de 'estándar' onde nós poñemos 'común'. As razóns deste cambio terminolóxico explicaranse na segunda sección do traballo. 


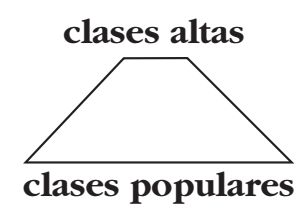

Figura 1. Variación dialectal segundo as clases sociais (Trudgill 1974: 41).

Así e todo, o diagrama deseñado na figura n ${ }^{\circ} 1$ presenta unha visión un tanto distorcida dos feitos, pois o grao de distancia lingüística entre os dialectos rexionais e a variedade estándar é variable: no caso galego, as falas do bloque central, especialmente as centro-septentrionais, atópanse máis preto do estándar cás do bloque occidental, probablemente as máis arredadas do estándar sexan as falas do galego extremo-oriental (en especial, o galego 'estremeiro').

En definitiva, concordamos con Halliday, Trudgill e a escola británica en que está xustificado considerar un eixo fundamental de variación 'sociodialectal'; non obstante, tamén nos parece útil, cando menos para analizar a situación do galego, distinguir ulteriormente un parámetro de variación diatópica e outro de variación diastrática

Outro reparo, de menor entidade, á proposta de Coseriu relaciónase coa consideración das 'variedades nacionais' das linguas de ampla difusión: neste caso, a variación ten unha obvia dimensión territorial, pero acostuma afectar ao plano normativo (mesmo á escrita: American British Spelling, ortografia brasileira portuguesa, etc.); de xeito que nos semella conveniente recoñecer un parámetro máis de variación diatópica, que atinxiría á norma. Así, poderiamos falar de variantes e variedades dianómicas ${ }^{18}$ como un tipo particular de variedades diatópicas. Tampouco isto nos vai interesar especialmente arestora. Finalmente, seguindo o criterio de varios estudosos, dentro do eixo diafásico (ou en íntima relación con este) coidamos conveniente distinguir un nivel de variación diamésica, definida segundo o medio ou canle de comunicación, que oporía a lingua falada e a lingua escrita (para a noción véxase Beruto 2004: 99-100; estudan a cuestión máis a fondo, entre outros, Biber 1988, Halliday 1990 e Leckie-Tarry 1995: 52-71).

En resumo, podemos considerar a variación sociolingüística estruturada nas seguintes categorías básicas:

\footnotetext{
${ }^{18}$ As variedades dianómicas sería os 'nomolectos', coma os distintos 'centros' das linguas pluricéntricas.
} 


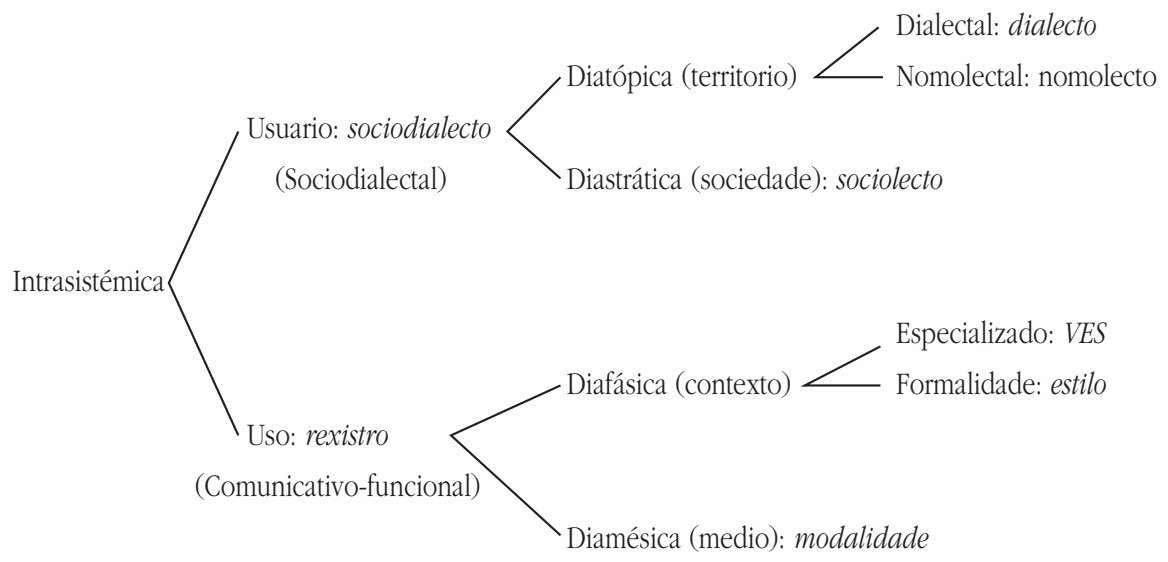

Intersistémica ou diaglósica: interlecto

3. VARIANTES E VARIEDADES: ObXeCtividADE, SUbXECTIVIDADE, REALIDADE INTERSUBXECTIVA

Un problema fundamental que presenta o estudo das variedades lingüísticas, análogo ao que acontece coas linguas, é o da súa realidade obxectiva. Richard Hudson, coherente coa súa posición acerca da imposibilidade de definir en termos estritamente estruturais as linguas (o mesmo que os seus correlatos, as 'comunidades lingüísticas'), precisamente a causa do seu carácter non homoxéneo e non discreto, considera que "non hai maneira de delimitar as variedades, e por tanto temos que concluír que as variedades non existen" (1996: 39). Para este autor, unhas e outras entidades existen só na medida en que as persoas son conscientes delas, de maneira que a súa realidade é meramente subxectiva. O único que tería existencia obxectiva serían as 'variantes', unidades mínimas marcadas con respecto a un dos eixos de variación (ou simultaneamente verbo de varios destes), e o que acontecería realmente é que no discurso o/a falante, dependendo da súa competencia, da situación en que se atopa e das súas intencións comunicativas, escollería variantes dun e outro tipo e combinaríaas (non sempre de xeito consistente, e en función, entre outros factores, da súa destreza) coa mira posta no efecto de comunicación procurado.

Hudson colócase aquí na perspectiva interaccionista con todas as súas consecuencias, seguindo a teoría dos actos lingüísticos como 'actos de identidade', formulada por Robert LePage, conforme a cal o locutor bota man "de regras sociais complexas para alternar e combinar elementos procedentes de varios códigos dun repertorio partillado", de modo e maneira que, "crea por si mesmo os modelos do seu comportamento lingüístico por mor de aproximarse aos [modelos] do grupo ou grupos con que en cada ocasión desexa 
ser identificado, e/ou para distanciarse daqueloutros de que desexa ser diferenciado" (LePage / Tabouret-Keller 1985: 180 e 181). Destarte, para LePage a combinación nun texto dado de variantes de distinto tipo non constitúe en absoluto unha anomalía. Na nosa opinión, Hudson está no certo ao constatar a dificultade de definición das variedades en termos obxectivos, pero chega a unha conclusión excesivamente radical, que se pode obxectar desde as dúas perspectivas: a inxenua (preteórica) dos falantes e a científica da sociolingüística.

Canto á primeira, será do caso invocar o célebre 'teorema de Thomas', segundo o cal se os individuos definen algo como real, é real nas súas consecuencias, do cal se segue que, no ámbito dos fenómenos sociais, a efectos prácticos non importa tanto que unha cousa sexa certa como que a xente a defina como tal. Se os individuos etiquetan as producións lingüísticas en termos de linguas e de variedades, e se esas distincións están firmemente ancoradas na súa consciencia metalingüística, como incorporadas ás tradicións culturais da comunidade (isto é, institucionalizadas na respectiva cultura lingüística), na práctica é como se esas entidades existisen, e a análise da realidade lingüística non as pode descoñecer -o cal non singifica, obviamente, tampouco se deban admitir acriticamente como base para unha pescuda científica. É certo que, tal como antes sinalamos, a existencia desas distincións é resultado de estereotipacións (e por tanto, de procesos de categorización en que criterios escasamente obxectivos e coherentes se aplican dun xeito abondo aleatorio), pero isto non torna en menos reais os efectos da súa aplicación polos falantes á hora de catalogar as prácticas lingüísticas e os seus produtos (os textos).

Doutra banda, e aínda máis importante, as variedades atópanse adoito definidas socialmente por un número limitado de trazos (fónicos, morfosintácticos e léxicos) aos que os locutores outorgan maior saliencia e que por tanto teñen carácter de sinalizadores do discurso. Estes sinalizadores teñen un papel moi importante na interacción, pois son empregados como síntomas da identidade social do falante e do nivel de formalidade da situación -por tanto das intencións comunicativas correspondentes-, e deste xeito suscitan determinado tipo de reaccións do interlocutor -entre outras cousas, xeran expectativas canto ao curso previsible da interacción.

Canto a isto, hai que advertir que do mesmo xeito que tendemos a percibir outras culturas en termos de diferenzas significativas da nosa propia (que poden ser irrelevantes naquela), cada locutor tende a oír a fala dos outros en termos de trazos salientes na súa propia, e a atribuírlle a estes unha significación social conforme aos seus propios esquemas valorativos, se cadra ignorando trazos lingüísticos que son socialmente significativos para outros locutores, ou pasando por alto a distinta interpretación social que os ditos 
trazos poden ter para estes. Esta observación é especialmente importante para os (socio)lingüistas: trazos que a estes lles parecen especialmente relevantes poden resultar secundarios ou insignificantes para os falantes. Inversamente, como veremos, estes poden outorgar relevancia a trazos que desde o punto de vista lingüístico parecen carentes de importancia ${ }^{19}$.

Pasemos arestora ao plano da teoría lingüística. Por vía da regra os enunciados lingüísticos ofrecen unha 'saturación típica' non só do que Labov denomina estereotipos, mais tamén do que el chama indicadores e marcadores: isto é o que nos permite clasificar tal enunciado / texto como pertencente a tal ou tal outro lecto ou variedade ${ }^{20}$. Canto a isto, debemos ter en conta que a relación entre as variables lingüísticas e as non lingüísticas é de natureza probabilística (máis/ menos), e non -ou raramente- de natureza categórica (presenza/ ausencia). Destarte, Berruto (1995: 152-58) propón concibir as variedades como constituídas arredor de focos onde se concentran feixes de trazos prototípicos, focos que marcarían o centro das categorías; por tanto, as principais variedades lingüísticas coincidirían con agrupamentos significativos e congruentes ('adensamentos') de trazos en puntos determinados do continuum lingüístico ${ }^{21}$. No mesmo senso, xa vimos antes que Ferguson sinala que "canto máis cohesionados se achan os sistemas, tanto máis nidias son as fronteiras; e canto máis son estes percibidos polos participantes como entidades separadas, tanto máis útil e analizalos como variedades lingüísticas" (1994: 23).

A este mesmo proceso dinámico e dialéctico (do plano obxectivo ao intersubxectivo e viceversa) de definición dos sistemas se refire LePage cando emprega o termo 'focalización', e xa advertimos previamente en que consiste o contributo dos gramáticos neste terreo: ao salientaren algúns trazos como 'típicos' dunha lingua, axudan decisivamente a definila, balizando as

19 O observador externo ten o problema de que tenderá a 'reinterpretar' dos trazos do grupo estudado en termos dos seus propios esquemas valorativos. O problema do observador interno é que corre o perigo de procurar confirmar os seus propios estereotipos.

${ }^{20}$ Lembramos que Labov (1983: 299-14; 387) distingue tres tipos de variables sociolingüísticas: (a) Os indicadores, variables que presentan unha distribución regular ao longo dos grupos sociais (de estatus, etarios, étnicos, etc.), pero son empregados por cada individuo máis ou menos do mesmo xeito en todos os contexto. Se tales contextos poden ser ordenados nunha escala xerárquica, daquela os indicadores están socialmente estratificados. Así e todo, os indicadores aparecen dotados de escaso poder avaliativo. (b) Os marcadores, variables que presentan unha distribución social e tamén unha diferenciación (unha estratificación) estilística. Aínda que adoito permanecen por debaixo do control consciente, trazos deste tipo poden suscitar respostas avaliativas regulares. (c) Os estereotipos, variantes socialmente marcadas, etiquetadas de forma notoria pola sociedade. Os trazos estereotipadores esbozan unha imaxe da estrutura sociolingüística da sociedade correspondente, unha imaxe case sempre parcial, escasamente sistemática e non de todo congruente.

${ }^{21}$ A noción de continuum será revisada, e matizada, de contado. 
fronteiras entre tal lingua e outras coas que portén ou está en contacto. Precisamente, como atrás anotamos e máis adiante desenvolveremos, neste punto o galego atópase actualmente aínda nunha situación abondo difusa e fluída, pero o proceso de estandarización está contribuíndo a focalizar e estabilizar as variedades, e ao mesmo tempo a definir o idioma propio fronte ao castelán.

Xa que logo, as dificultades que ofrece a definición 'científica' das linguas e dos lectos (dos 'polisistemas' e dos 'subsistemas' lingüísticos) non os tornan seres ficticios, fantasmagorías dos falantes ou entelequias caprichosas dos lingüistas: na práctica, as persoas distinguen variedades (como tamén distinguen linguas) e actúan en consonancia con esas distincións, de maneira que estas entidades existen nos seus cerebros e condicionan a súa visión da realidade e o seu desempeño lingüístico. Endebén, o que resulta de crucial importancia, para evitar confusións, é deixar claro que unha cousa é moverse no plano 'intersubxectivo' dos locutores e outra no plano 'obxectivo' dos (socio)lingüistas. No plano intersubxectivo, debemos falar en termos dos trazos estereotipadores e das avaliacións socioculturais que os falantes activan no curso das interaccións lingüísticas co gallo de modular a produción lingüística propia e de interpretar a dos seus interlocutores. No plano obxectivo, debemos falar das variables que identificamos mediante a análise metódica e sistemática dos produtos lingüísticos, e da correlación entre as devanditas variables e os parámetros sociais correspondentes.

Consecuentemente, cadramos consteste con Berruto cando xustifica a noción de variedade, xa que "o recoñecemento e a identificación de variedades, como feixes de variantes nos distintos niveis da análise que correlacionan con factores sociais, é un achado fundamental da sociolingüística e ademais representa un momento irrenunciable do necesario proceso de abstracción que a teoría e a análise científica deben realizar perante a ilimitada variabilidade e caoticidade do real" (2004: 98) ${ }^{22}$.

4. Arquitectura do sistema. Gradación, multidimensionalidade, Xerarquía

Podemos concibir, pois, a lingua como un sistema polilectal; ora, problema distinto é establecer como se artellan esas variedades para configurar a arquitectura dun sistema tal. Tense presentado unha concepción da lingua

\footnotetext{
22 Desde este punto de vista son comprensibles as reservas (que partillamos) deste autor fronte á sociolingüística interaccional, na que advirte o perigo de "transformar a análise nunha reprodución fractal do real" (Berruto, 1995: 46-50).
} 
como un continuum lineal e unidimensional de lectos ordenados nunha escala implicacional ${ }^{23}$. Esta era a imaxe incialmente proposta por algúns creolistas, unha visión xustamente criticada por LePage / Tabouret-Keller (1985: 180-86), que dá conta só parcial do fenómeno da variación, e fronte a cal estes autores defenden un modelo radicalmente contraposto das linguas como espazos multidimensionais e repertorios abertos, nos cales, tal como quedou atrás dito, os falantes, ao produciren un texto e en función da súa competencia, o contexto, a audiencia, e as súas intencións comunicativas e expresivas, escollen variantes marcadas por unha determinada connotación socioestilística. Pola súa banda, Berruto propón un modelo de arquitectura da lingua disposto en forma un gradatum escalar multidimensional, orientado entre polos opostos, no cal as variedades emerxen como puntos de adensamento de trazos (Berruto 1995: 152-58).

Vexamos. Das variedades entendidas como 'focos' ou puntos de adensamento de trazos prototípicos falamos xa antes. A idea de gradatum coidamos que resulta máis precisa cá de continuum: a primeira supón unidades discretas, con transicións graduais e non fronteiras tallantes entre elas; a noción de continuum indicaría simplemente que non hai posibilidade de distinguir unidades discretas, dada a borrosidade das fronteiras. A multidimensionalidade remite ao cruzamento inextricable e á combinación transversal de varios eixos de variación, ao carácter 'holográfico' do fenómeno da variación, de maneira que cada variante pode atoparse posicionada simultaneamente en relación con varias dimensións. A característica de multidimensionalidade do espazo lingüístico debemos entendela como explicitamente contraposta á de ordenación en escala implicacional: unha configuración multidimensional é necesariamente distinta a unha implicacional. Verbo disto, Berruto aclara:

As tres dimensións de variación non actúan illadamente, mais interactúan e interfírense en varios modos. En primeiro lugar, unha produción lingüística concreta dun falante calquera terá sempre unha colocación simultánea verbo dos tres eixes: diatópico, diastrático e diafásico. En segundo lugar, trazos lingüísticos orixinaria e primariamente marcados como diátopicos poden asumir valor (aínda máis) marcado diastraticamente, e trazos marcados en orixe como diastráticos poden asumir valor marcado diatopicamente, de xeito tal que as marcaxes diatópica, diastrática e diafásica se presentan adoito inextricablemente copresentes (Berruto 1995: 149-50).

${ }^{23}$ É o modelo que Dubert 2002 tenta aplicar ao galego. Tamén houbo tentativas, máis arriscadas, de aplicalo á escrita (Álvarez Cáccamo / Herrero Valeiro 1996). 
Unha idea semellante é expresada por R. LePage ao aseverar que "os dialectos e rexistros solápanse considerablemente: o dialecto dunha persoa é un rexistro para outra" (1996: 47). A figura que Labov ofrece da estratificación socio-estilística da variante [in] do segmento -ing en final de palabra é moi ilustrativa do que estamos a dicir (véxase figura 1).

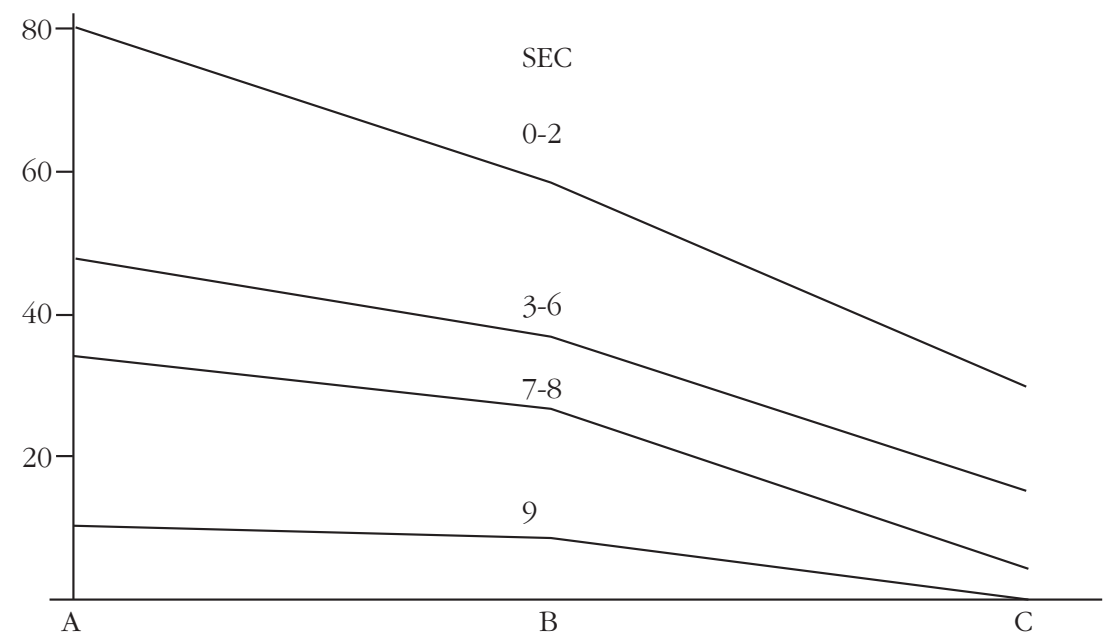

Figura 2. Estratificación socio-estilístida de [in] para -ing entre adultos brancos neoiorquinos, segundo Labov (1983: 301).

Xa que logo, determinadas variantes poden asociarse a máis dun tipo de 'lecto', e mesmo poden mudar de estatus: como antes sinalamos, a gheada, por exemplo, que en principio é unha variante diatópica, pode converterse nun momento dado ou para certos falantes nunha variante estilística; e isto non implica que necesariamente perda o carácter anterior de variante diatópica. Para quen escribe estas liñas, o dialecto (galego) de orixe constitúe hoxe nunhas ocasións unha variedade contextual (empregada segundo os interlocutores) e noutras unha variedade estilística (usada en 'estilo alternativo', con efectos expresivos e en particular humorísticos). Similarmente, o castelán é empregado por moitos galegofalantes, ademais de como variedade contextual (dependendo dos interlocutores ou ás veces do escenario institucional da interacción), como variedade estilística (expresiva e tamén frecuentemente escarniña).

Destarte, as certeiras observacións de Coseriu sobre o aspecto 'multidimensional' da variación lingüística (el non emprega este adxectivo) son merecentes dunha maior concreción. En principio, parece certo que en cada dialecto se poden comprobar diferenzas diastráticas e diafásicas, en cada nivel, diferenzas diatópicas e de estilo, e así sucesivamente. Pero non é menos certo que tanto a magnitude real da variación canto a súa percepción polos falantes e a interpretación social a que se acha sometida non é equiparable 
para todos os casos. Por vía de exemplo: en teoría, poderíase escribir un tratado de metafísica nun dialecto, pero na práctica os dialectos non adoitan empregarse nese tipo de textos. Por parte, a 'lingua común' pode presentar matizacións dialectais máis ou menos marcadas ('variedades rexionais') pero o rango e a escala de variación diatópica é nela, por definición, moito máis reducido do que existe entre os dialectos territoriais. Como veremos máis adiante, estes matices non carecen de importancia des que tentamos obter unha imaxe minimamente precisa da arquitectura da lingua.

Acabamos de apuntar que as variedades ou lectos adoitan atoparse definidas por un número relativamente reducido de variables. Xa que logo, non debemos concibir cada variedade como un sistema feito e dereito, isto é, caracterizado por un completo abano de trazos que o caracterizan da cima ao cabo, en todos e cada un dos planos da lingua (do fónico e morfolóxico ao semántico e o pragmático): un lecto é un subsistema, isto é, constitúe unha agrupación de variantes congruente pero incompleta; non é un microsistema, ou sexa, non consiste nunha versión reducida dunha lingua. A variación lingüística presenta un rango, amplitude e configuración distintos conforme o parámetro en que nos movamos (diatópico, diastrático, diafásico...), no senso de que o tipo e cantidade de trazos caracterizadores non son equivalentes para todas e cada un dos lectos identificables en todos e cada un dos parámetros: certos lectos poden acharse caracterizados por un número elevado de variables, outros por un número reducido; ademais, estas variables poden pertencer, segundo os casos, ao plano fónico, morfolóxico, sintáctico, léxico, semántico, ou pragmático, sós ou en calquera tipo de combinación.

Coseriu sostén que os dialectos xeográficos acostuman ser máis completos do punto de vista lingüístico (isto é, atoparse máis e mellor caracterizados nos distintos planos da lingua), en canto que as variedades sociais e contextuais se achan caracterizadas dun xeito moito máis parcial (en termos coserianos, son 'formas só parcialmente diverxentes da lingua común'): "O dialectal caracteriza integramente un xeito de falar, mentres que os feitos caracterizadores dos niveis e estilos de lingua atinxen xeralmente só a aspectos parciais (aínda que, ás veces, de validez intrínseca moi ampla)" (Coseriu 1981b: 16). De aquí deriva a idea de que existe unha 'xerarquía' das variedades, unha idea que expresa moi ben o colega Dubert (2002: 14-16): "existe unha xerarquía de ordenación das variedades, de modo que a primeira gran división é a diatópica; dentro de cada xeolecto [dialecto] existirán diferentes sociolectos; e dentro de cada sociolecto, un conxunto de estilos"24.

A devandita idea, en rigor, é incompatible co modelo 'multidimensional' da variación lingüística tal como o propón LePage. En troca, coido que pode

${ }^{24}$ Véxase para isto tamén Berruto 1995: 150-51. 
ser compatible con este -e máis conforme á realidade efectiva da variación tal como se manifesta no uso da lingua- se reformulamos a defición de ambos e somos máis precisos canto ao número, tipo e entidade das variables afectadas por cada un dos parámetros de variación. Canto ao primeiro, coido que nin o modelo de sistema polilectal estruturado presupón forzosamente que as variantes se achan meticulosamente estibadas unhas con outras en paquetes compactos e indisolubles (os lectos), á súa vez rixidamente arranxados nunha xerarquía inflexible; nin o modelo multidimensional implica por forza a noción dun repertorio lingüístico caótico, do espazo lingüístico como un totum revolutum onde un pandemonio de variantes disxuntas flutúa estradas sen orde nin concerto.

Canto á correlación entre eixos de variación e número, tipo e entidade das variables afectadas, algo dixemos antes; a isto engadimos agora: a variación dialectal afectaría unhas determinadas variables gramaticais (sobre todo fónicas e morfolóxicas, en menor medida, léxicas e sintáticas), e seccionaría verticalmente o sistema lingüístico, mentres que a variación socio-funcional afectaría outra serie distinta de variables (algunhas fónicas e morfosintácticas, pero sobre todo léxico-semánticas e pragmáticas), e seccionaría o sistema lingüístico transversalmente, en senso oblicuo. Nesta liña, será interesante evocar aquí unha hipótese de Hudson (que o mesmo autor califica como "moi tentativa") segundo a cal a sintaxe é o marcador da cohesión da sociedade, o léxico é o marcador das divisións sociais, e a pronuncia reflicte o grupo social permanente co que o falante se identifica; xa que logo, os falantes tenderían a eliminar do seu idiolecto as variantes sintácticas e en troca a cultivar activamente alternativas léxicas para marcar distincións sociais sutís (Hudson 1996: 45).

A proposta de Hudson repousa na idea tradicional de que o núcleo 'fundamental' da lingua residiría na sintaxe, o menos variable de todos; os planos morfolóxico e fonolóxico situaríase, nesa orde, nun nivel menos profundo, e resultarían máis variables, e o léxico atoparíase nunha posición máis periférica, e sería o máis variable dos tres. O dialecto presentaría variables características nos tres planos, o sociolecto máis ben no fónico e no léxico (e menos no morfosintáctico) e o estilo máis no léxico (menos no fónico, e menos aínda no morfosintáctico). Tomado en groso e en xeral, tal cadro pode reflectir dun xeito aproximativo a percepción dos propios falantes, e incluso a intuición de boa parte dos lingüistas. Endebén, a análise a fondo revela que a variación sintáctica e semántica nos eixos social e funcional (e non digamos xa entre lingua falada e escrita) é bastante maior do que poida parecer a primeira vista ${ }^{25}$. 25 A título de exemplo, véxase o magnífico traballo sobre variación sintáctica entre distintos rexis-
tros do galego realizado por Cidrás Escáneo 1994. Son moi numerosos os traballos sobre as di- 
Será interesante introducir aquí unha reflexión sobre os diferentes comportamentos verbo da variación que ofrecen as linguas sen normalizar ('incompletas'), en comparanza coas linguas normalizadas ('completas'). Isto é, linguas que non experimentaron un amplo despregamento funcional (parámetros socio-comunivativos) e que non están estandarizadas (parámetros lingüísticos), fronte a aqueloutras estandarizadas e funcionalmente desenvolvidas. Por vía da regra, as primeiras caracterízanse por unha variación xeográfica relativamente maior -con eventual deriva cara á fragmentación dialectal- fronte a unha escasa diversificación nas dimensións social e funcional; mentres que as segundas, pola contra, adoitan ser dialectalmente máis compactas -adoito cunha tendencia cara á redución das diferenzas e incluso cara á homoxeneización, fóra o caso da variación dianómica nas linguas de extensión internacional-, e mostrarse máis diversificadas nas outras dúas dimensións (social e funcional). O galego, unha lingua en proceso de desenvolvemento, está experimentando unha diversificación social e estilística inédita, o cal constitúe, case inevitablemente, unha fonte de perplexidades e mesmo de tensións ${ }^{26}$. Volveremos sobre isto.

\section{A VARIACIÓN DIAFÁSICA OU SOCIO-FUNCIONAL: REXISTRO / ESTILO}

E con isto chegou o momento de referirse a un dos paramétros da variación lingüística: a diastrática, a que nos permite definir os rexistros ou esti$\operatorname{los}^{27}$. Nas súas pescudas sociolingüísticas, Labov (1983: 105-53) ten empregado o termo 'estilo (contextual)' nun senso restrinxido, como pauta regular de variación na produción oral (en particular, na pronuncia) que depende da atención que o locutor presta ás formas lingüísticas que emprega na súa fala, unha atención que varía en función da situación comunicativa. A Labov interesáballe dun xeito moi concreto establecer unha grella de 'estilos' útil para analizar o material lingüístico recollido en investigacións de campo. Segundo isto, o noso autor distingue: contexto-estilo A (situación informal/ discurso

ferenzas entre lingua escrita e falada, con atención ao aspecto léxico-semántico e ao sintáctico (Halliday 1990 ofrece un bo exemplo). Canto á variación sociolectal, a prolongada discusión sobre a hipótese dos dous códigos (restrinxido e elaborado) e a teoría do déficit, é boa testemuña da profundidade das diferenzas. Véxase, entre outros, Bernstein 1971/1972/1975 e Halliday 1979: 24-31 e 101-07.

${ }^{26}$ Sobre isto saliento entre a abundante bibliografía os traballos de Kabatek 1991, 1996a e 1996b; Regueira 1994, 1997, 1999 e 2002; e Vidal 1997. Pódense ver as miñas consideracións ao respecto en Monteagudo 2002b, en particular as pp. 113-120.

27 Salvo indicación expresa en contrario, seguindo o uso xeral, empregaremos 'rexistro' e 'estilo' como sinónimos. 
casual), contexto B-estilo A (situación formal/ discurso espontáneo), contexto-estilo B (situación formal/ discurso coidado), contexto-estilo C (lectura de texto), contexto-estilo D (lectura de listas de palabras), contexto-estilo D' (lectura de pares mínimos). ${ }^{28}$ A proposta de Labov ten basicamente un carácter analítico e metodolóxico, e está, como dixemos, pensada para a recollida e tratamento de textos orais; o estudoso americano non pretende deseñar unha tipoloxía 'universal' (sen ir máis lonxe, un falante analfabeto carece dos 'estilos' C, D ou D' tal como os define Labov ${ }^{29}$. Temos aí, por tanto, unha primeira acepción específica do termo 'estilo'.

Obviamente, todos os locutores modulan a súa fala en función do contexto de comunicación, de maneira que todos eles posúen un abano de estilos; de feito, a destreza para adaptar a fala ao contexto constitúe un compoñente básico da competencia comunicativa ${ }^{30}$. Debemos de coidarnos de considerar os falantes como 'autómatas' que se limitan a aplicar uns guións de conduta lingüística pre-establecida ás situacións comunicativas en que se ven involucrados. Pola contra, os interlocutores e o texto non son engranaxes pasivos dun mecanismo socio-funcional, mais o locutor pode participar activamente na definición da situación, empregando como recurso precisamente o seu discurso (isto é, o uso da lingua). Doutra banda, o que un locutor pode categorizar como 'estilo coidado' pode ser catalogado por outro como 'estilo espontáneo' (para non saírmos dos termos empregados por Labov).

No entanto, a variación estilística non só pode contemplarse desde a perspectiva do locutor nun nivel 'micro', mais tamén desde a persectiva social, do nivel 'macro'. Desde a perspectiva macro, podemos pois constatar que, aínda que todos os falantes posúen un abano de estilos, este non necesariamente coincide co repertorio de estilos socialmente recoñecidos (Ure

\footnotetext{
${ }^{28}$ Das anteriores, a única distinción merecente dunha explicación é a que establece entre o discurso casual "a fala cotiá empregada en situacións informais, sen ningunha atención á lingua", e o discurso espontáneo, definido como "unha contrapartida ao discurso casual que se dá en contextos formais, non como resposta a unha situación formal, mais precisamente a pesar dela" (de aí que se fale de contexto B, isto é formal, e estilo A, isto é, informal); trátase dunha "fala cargada de excitación ou de emoción, onde as constriccións dunha situación formal desaparecen" (Labov 1983: 124).

${ }^{29}$ Secomasí, cos analfabetos, aínda que carecen de estilo de lectura, poden posuír o de recitado (dun texto que saiban de memoria), e algo similar acontece coas listas de palabras (nas enumeracións dos días da semana ou ou meses do ano, por exemplo); análoga observación vale para os pares mínimos.

30 Concordamos, pois, neste punto, coa posición de Dubert: "todo falante normal debe, cando menos, saber producir textos nunha serie de estilos máis ou menos formais" (2002: 18). Secomasí, no que vén a seguir matizaremos o alcance desta afirmación.
} 
1982: 6). Máis aínda, non todos os falantes dominan este repertorio: case calquera falante é capaz de improvisar un discurso máis ou menos lucido en estilo formal ante unha audiencia regularmente ampla (por caso, unha breve alocución de boasvindas, unha felicitación ou un agradecemento nunha festa familiar), pero poucos son quen a desenvolver unha disertación solemne ante un auditorio amplo e anónimo. Xa que logo, todos os locutores dispoñen dunha competencia parcial en varios rexistros, e todos son capaces de se adaptar á situación en que se ven involucrados; pero con máis ou menos destreza ou acerto segundo o falante e o rexistro manexado. Por tanto, podemos recoñecer unha segunda acepción do termo 'estilo', para nos referirmos a cada unha das variedades socialmente recoñecidas:

A escala de rexistros lingüísticos comprende o abano de situacións situacións sociais recoñecidas e controladas polos seus falantes, situacións para as que existen modelos apropiados. Cada comunidade lingüística posúe o seu propio sistema de rexistros, que corresponde co repertorio de actividades en que os seus membros participan de xeito habitual (Ure 1982: 1).

E velaquí como se interconectan e solapan os distintos parámetros de variación, pois o acceso ao comando en rexistros 'elevados' dependenderá en boa medida do nivel de instrución, da riqueza relativa de experiencias e da posibilidade de acceso a determinados recursos culturais, factores estes obviamente mediados polo estatus social (Berruto 1995: 142-46). En efecto, en todas as comunidades lingüísticas mininamente desenvolvidas un discriminante sociolingüístico importante vén constituído pola destreza no manexo da lecto-escritura, pola competencia na variedade estándar e polo comando dos rexistros lingüísticos elevados que esixen a utilización desta ${ }^{31}$.

O fenómeno devandito non nos debe levar a confundir a variación diafásica coa social: é un feito que os membros dos grupos sociais acomodados, en virtude precisamente do seu estatus, gozan dun mellor acceso, máis ocasións de uso e por tanto maior dominio dunha serie de variedades lingüísticas, ao contrario do que acontece cos grupos sociais desavantaxados; pero ese feito non converte automaticamente esas variedades en 'variedades sociais'. A asociación entre dunha banda a variedade estándar e os rexistros elevados de lingua (igual cá lecto-escritura) e doutra os grupos sociais privi-

\footnotetext{
${ }^{31}$ Nótese pois como se pode denunciar como unha falacia a visión da lingua como un patrimonio comunitario partillado equitativamente por todos os falantes, posuidores dunha competencia lingüística equivalente. Obviamente, as destrezas lingüísticas, e máis aínda as comunicativas, atópanse desigualmente repartidas (véxase sobre isto Bourdieu 1982: 23-25).
} 
lexiados é socio-cultural e continxente, non é intrínseca e necesaria. Por iso mesmo, os grupos sociais desfavorecidos teñen todos os argumentos para non posicionarse contra a variedade estándar e os rexistros elevados; ao revés, o lóxico é loitar activamente contra a marxinalización ou exclusión destes canto á apropiación e uso de tales recursos lingüísticos. O rexeitamento do estándar e dos rexistros elevados en nome das connotacións sociais que hogano leva asociado o seu emprego resulta tan insensata como o resultaría o rechazo da alfabetización das masas hai cen ou cincuenta anos, fundado en argumentos do mesmo tipo.

As dimensións da variación contextual ou diafásica son dabondo complexas, pois, como di Hudson, "diferentes elementos lingüísticos son sensibles a diferentes aspectos do acto de comunicación, do mesmo xeito que diferentes elementos reaccionan de xeito distinto ás diferentes características (sociais) do falante" (1996: 47). Daquela, tornamos á noción de estilo/ rexistro, tal como aparece definida por Halliday (véxase táboa $n^{\circ} 1$ ): unha variable dependente do uso, ou máis, particularmente, do contexto. Son diversas as tentativas de definir os factores contextuais relevantes para definir un acto de fala, que constituirían os reguladores do estilo/ rexistro correspondente ${ }^{32}$. Así, tense sinalado que o estilo/ rexistro depende: (1) dos locutores que interveñen na situación comunicativa e da súa mutua relación (grao de familiaridade), (2) do escenario da interacción (formalidade da ocasión) e (3) do asunto (funcións ou propósito do acto de comunicación). O propio Halliday preferiu definir o contexto en función dos tres principais tipos de factores situacionais que determinan os tipos de selección de elementos lingüísticos: a) Campo (field): escenario institucional (tema/ actividade en marcha, ámbito...); b) teor (tenor): relacións entre os participantes (familiaridade, estatus, rol, emoción...); c) modo (mode): canle de comunicación (fala/ escrita, teléfono...).

O 'campo' refírese á actividade que ten lugar, o 'teor' aos participantes nela, o 'modo' ao papel que xoga a lingua. Unha das variables que se inclúen no modo é a que podemos denominar 'medio' (medium), que opón o discurso oral ao discurso escrito. Como é evidente, a distinción entre o rexistro oral e o rexistro escrito non é só de 'medio' de transmisión, mais ten unhas implicacións de moito alcance, que non aquece sinalar agora ${ }^{33}$, de aí que estimemos xustificado distinguir un eixo de variación diamésico, ao que nos referimos antes. De feito, cando tratamos o asunto da variación na pers-

\footnotetext{
32 Un esquema detallado dos 'compoñentes da situación de comunicación' ofréceneo Brown / Fraser 1979: 35. Véxase tamén Giles / Coupland 1991: 1-31.

${ }_{33}$ Para unha introdución, sumaria pero esclarecedora, véxase Halliday 1990.
} 
pectiva da lingua normativa, debemos deixar constancia de que a prescrición se refire primariamente e atinxe fundamentalmente á escrita. Ora, o discurso formal oral constitúe practicamente un discurso de oralidade secundaria (isto é, mediado pola escrita ou dependente deste), e algo semellante, aínda que nunha medida moito menor, se podería dicir do semiformal (Ong 2002) ${ }^{34}$.

Outra dimensión da variación estilística, moi importante no proceso de modernización da lingua, é a relacionada coa creación de rexistros especializados (VES), asociada á ampliación do abano de actividades en que esta lingua é empregada (Ure 1982). Os rexistros especializados poden clasificarse en dous parámetros: tipo (relacionado co tema) e grao de especialización. Este aspecto da cuestión, que temos tocado noutros traballos, non nos aquece arestora $^{35}$. Obviamente, o subdesenvolvemento estilístico do galego é consecuencia directa da diglosia, en concreto, da súa vertente funcional.

Finalmente, afirmamos antes que o locutor non era un autómata; sinalamos tamén que a súa competencia comunicativa (desigual de falante a falante segundo o estilo) é un factor determinante, subliñamos agora que á parte dos elementos obxectivos que imos considerar a seguir, existen uns factores subxectivos que adoito son ignorados cando se trata do estilo. Referímonos en particular a dous aspectos que son moi difíciles de capturar nunha visión sintética da cuestión, pois están subsumidos na etiqueta do teor: o carácter denotativo versus coloración connotativa dos textos (cos seus matices e diferentes niveis de intensidade: dramática, irónica, satírica, humorística, afectiva , ...) e mais á expresión lingüística das actitudes respecto a outros interlocutores (afecto, indiferenza, agresividade, deferencia...).

\footnotetext{
${ }^{34}$ Ademais de rexistro/ estilo, do que falamos previamente, teñen sido empregados outros termos en referencia á variación contextual, tales como 'xénero' e 'tipo de texto'. Así, segundo Ferguson, 'rexistro' está asociado a unha "situación comunicativa que ocorre regularmente na sociedade" mentres que xénero se refire a un "tipo de mensaxe que ocorre regularmente nunha sociedade" (1994: 20-21). Pola súa banda, Biber ten definido o xénero como "categoría de textos que o falante maduro dunha lingua distingue inmediatamente, por caso, novela, artigo de xornal, editorial, contributo académico, conferencia, programa de radio, conversa ordinaria" (1995: 8). Nesta liña, este mesmo autor recolle a definición de 'xénero' como "instancia convencional de organización textual". Como se ve, trátase dunha noción moi próxima á de 'rexistro', se acaso incidindo máis no aspecto do contido e do formato do texto do que nos aspectos extra-textuais. Canto aos 'tipos de texto', Biber enténdeos como categorías establecidas en termos estritamente lingüísticos, definidas de tal xeito que os textos de cada tipo son maximamente similares no tocante ás súas características lingüísticas, mentres que cada un dos tipos é maximamente diferente aos outros no tocante ás ditas características. Eu mesmo teño empregado reiteradamente as designacións 'xénero comunicativo/ tipo de texto' (véxase por caso Lamuela / Monteagudo 1996: 281-83

35 Véxase, por caso, Lamuela / Monteagudo 1996: 281-94.
} 


\section{ReXISTROS E GRAO DE FORMALIDADE}

Dado que no presente contributo só pretendemos unha aproximación á cuestión, unha vez deixamos constancia da proposta de Halliday e das precisións de Biber, ímonos referir dun xeito esquemático á cuestión da variación diafásica, atendendo ao criterio principal xeralmente empregado para unha primeira aproximación ao rango de estilos/ rexistros: o grao de formalidade. Na nosa opinión, a 'formalidade' é unha noción complexa que captura sinteticamente varios dos aspectos máis decisivos da situación de comunicación, particularmente nas dimensións do campo e o teor. Así, o grao de formalidade depende esencialmente do ámbito de comunicación (asociado a certo tipo de actividades) e do tipo de relacións entre participantes. Canto ao primeiro, pódense distinguir entre outros os ámbitos públicos (coma os relacionados coa comunicación institucional e certos ritos relixosos ou cívicos), semipúblicos (coma os da comunicación individual de carácter profesional ou corporativo), privados (coma os relacionados coa sociabilidade entre pares) e íntimos (coma os das relacións familiares). Canto ao segundo, factores relevantes poden ser a distancia ou escasa familiaridade, ou ben notables diferenzas de estatus (como entre unha persoa maior e outra persoa moza) ou asimetría de roles (como nas interaccións profesor $\leftarrow \rightarrow$ estudantes, cliente $\leftarrow \rightarrow$ dependente, xefa $\leftarrow \rightarrow$ subordinados, médico $\leftarrow \rightarrow$ paciente) entre os interlocutores.

Segundo o nivel de formalidade, podemos distinguir tres rexistros básicos (véxase a táboa $n^{\circ}$ 2), tanto na fala coma na escrita, que resultan da distinción entre tres niveis de monitorización do emisor verbo da súa propia actuación lingüística: un nivel de máximo control, no rexistro formal (mensaxe reflectida, suxeita a planificación previa; acto de emisión tenso, que se manifesta, por exemplo, nunha menor velocidade de emisión); un nivel de control medio, no rexistro semiformal; e un nivel de control mínimo, no rexistro informal (mensaxe improvisada ou espontánea, acto de emisión distenso, que se manifesta nunha maior velocidade, por caso).

O contexto-tipo que corresponde ao rexistro formal é o da comunicación impersoal, xeralmente pública (ou entre interlocutores descoñecidos) e institucionalmente mediada (literatura, ritos cívicos ou relixiosos, etc.), polo que se caracteriza polos trazos 'tenso' (mesmo tensión articulatoria, no caso da fala) e 'reflectido' (o discurso é frecuentemente elaborado con moito coidado, como é o caso da literatura), o rexistro formal falado, como dixemos, depende estreitamente do escrito. O contexto-tipo do rexistro semiformal é o das comunicación semi-públicas, entre persoas pouco coñecidas, en situacións que obrigan a un certo distanciamento e/ ou impoñen certa xerarquía entre os interlocutores, o que obriga a un control medio sobre a comunicación. O contexto-tipo que corresponde ao rexistro informal é o da comunicación pri- 
vada, entre persoas coñecidas, en situacións que non impoñen distancias nin xerarquías ríxidas entre os participantes, de maneira que se caracteriza polos trazos 'distenso' (mesmo na articulación da fala) e 'espontáneo'.

$\begin{array}{clc} & \text { REXISTROS } & \\ \text { tenso } & \text { FORMAL } & \text { [+CONTROLADO }] \\ & \text { SEMIFORMAL } & \\ \text { distenso } & \text { INFORMAL } & \text { espontáneo } \\ \text { [-CONTROLADO }] & & \end{array}$

Táboa 2.- Tres rexistros básicos da fala e da escrita. Elaboración propia

Esta división tripartita (continuadora da clásica en sermo illustris, sermo mediocris e sermo humilis) é suceptible dunha maior matización (táboa $\mathrm{n}^{\mathrm{o}} 3$ ), por caso distinguindo dentro do rexistro formal falado o oratorio (solemne), o esmerado (serio) e o impersoal (distante), dentro do rexistro formal escrito o literario (da creación ficional), o cultivado (da prosa elaborada) e o instrumental (prosa informativa e documentaria). Analogamente, dentro do rexistro informal na fala distinguiriamos o rexistro coloquial (relaxado), o familiar (afectivo) e o alternativo (o máis expresivo, o que os lingüistas italianos denominan graficamente como 'turpiloquio'), mentres que na escrita distinguiriamos o rexistro cursivo (ordinario), o trivial (descoidado) e o transgresor (efectista). Non seguimos por esa liña, pois non é o noso obxectivo ofrecer aquí unha nomenclatura ou clasificación exhaustivas nin unha xustificación pormenorizada dos distintos estilos de fala e escrita en galego, tarefa que require un traballo previo de investigación empírica que, polo que sabemos, non foi aínda abordado.

Gustaríanos, iso si, chamar a atención para os estilos tradicionalmente denominados 'vulgares', designación esta que nos parece cargada de connotacións sociais e prexuízos valorativos, que o vencellan ás 'clases inferiores' e aos individuos incultos. Dunha banda, cando na bibliografía lingüística se fala de 'vulgarismo' habitualmente se denota unha fala caracterizada polo que confusamente se denominan barbarismos (isto é, 'impurezas' na pronuncia) e solecismos (aínda que este termo adoita referirse máis ben ás 'faltas' na sintaxe), no cal basicamente se engloban pronuncias ultra-vernáculas $^{36}$ e diversos metaplasmos típicos dos falantes non instruídos. Trátase,

\footnotetext{
${ }^{36}$ Este tipo de variantes adoitan ser o resultado da acomodación á fonémica vernácula de empréstimos cultos ou de estranxeirismos ('poblema', 'efeuto', 'ademirar', etc.); por iso é aínda máis chocante referirse a elas como 'barbarismos'.
} 
pois, dun fenómeno máis ben de variación social que non estilística. Doutra banda, cando se fala de 'linguaxe vulgar' remítese ao que que os lingüistas italianos, con termo ben gráfico, denominan 'turpiloquio', isto é, o emprego de vocábulos disfémicos ou tabús; este emprego pode tamén correlacionar coa identidade social do falante ${ }^{37}$, pero préstase tamén ao xogo dos 'estilos'. É neste último senso que empregamos os termos de estilo 'alternativo' na fala e 'transgresor' na escrita, que fan referencia ao seu carácter marxinal e anticonvencional, conforme o sistema de valores dominante.

\begin{tabular}{clc} 
& \multicolumn{1}{c}{ FALA/ESCRITA } & \\
& & \\
oratorio $\leftarrow$ literario & [+CONTROLADO $]$ \\
& esmeflectido \\
& impersoal $\leftarrow$ instrumental & \\
& coloquial $\rightarrow$ cursivo & \\
& familiar $\rightarrow$ trivial & \\
& alternativo $\rightarrow$ transgresor & espontáneo \\
distenso & &
\end{tabular}

Táboa 3. Seis rexistros na fala e na escrita. Elaboración propia

$\mathrm{Na}$ táboa $\mathrm{n}^{\circ}$ 3, a dirección das frechas indica que mentres nos rexistros 'altos' é basicamente a lingua escrita a que marca a pauta e a lingua falada recibe a influencia desta, nos rexistros 'baixos' acontece o contrario. Os casos extremos son ilustrativos: o rexistro oratorio resulta, por vía da regra, da lectura en vOz alta dun texto escrito; o rexistro transgresor resulta dunha imitación deliberada na escrita (adoito, literaria), do estilo alternativo da fala aínda que aquí tamén entraría determinado tipo de inscricións murais).

Lembramos que estes rexistros, tal como nós os concibimos, non correlacionan directamente coa posición social do falante (non se confunden, pois, cos sociolectos), mais, insistimos, coa situación de comunicación. Isto non significa que non exista unha asociación entre a dimensión funcional e a social, pero esta asociación non é directa, mais está mediada polo nivel educativo: en particular, para dominar o rexistros formais cómpre posuír unha competencia lingüístico-comunicativa considerablemente elevada, que practicamente só se pode obter mediante a educación formal. Por outra banda, a ocasión de exercer de 'protagonista' (emisor principal, se se quere) dunha interacción realiza-

\footnotetext{
37 Tanto en termos de clase social/ nivel de instrución coma por caso de grupo etario: sábese que os falantes instruídos recorren menos (ou incluso evitan) o turpiloquio; doutra banda, os falares xuvenís recréanse no palabrón.
} 
da nun contexto/ situación formal (isto é, que esixe o emprego estilo formal) non se lle presenta a todo o mundo, mais soamente a individuos que gozan dun determinado estatus institucional, un estatus máis accesible para persoas de clase social acomodada. Secomasí, reiteramos, non se pode confundir a variación estilística coa diastrática, pois son dous fenómenos de natureza diversa, e, salvo en casos particulares, a primeira correlaciona só indirectamente coa segunda. De feito, cando tratamos de variación diastrática, ao que nos referimos, en principio, é á lingua falada e aos estilos coloquial e familiar.

\section{VARIACIÓN DiASTRÁtiCA. LiNGUA, DisCuRSO E ACTOS DE IDENTIDADE}

Para podermos categorizar as variantes e a partir de aí establecer as variedades sociolingüísticas, cómpre dispoñer previamente dunha definición minimamente operativa das variables extra-lingüísticas relevantes. Así, as variables de xénero/ sexo e idade son relativamente doadas de definir e de manexar, pois permiten delimitar cun grao satisfactorio de claridade grupos ben identificados, tamén desde o punto de vista sociolingüístico -aínda que adoito máis por trazos paralingüísticos (cualidade e timbre da voz, entoación) e discursivos (pautas de comunicación) do que propiamente lingüísticos. Algo similar, embora xa non tan claramente, podemos dicir da variable 'hábitat': o ambiente e as características lingüístico-comunicativas dos núcleos urbanos maiores é claramente distinto (comezando pola súa maior complexidade) ao dos poboamentos rurais, e ambos máis ou menos discernibles dos das vilas medianas e pequenas. A variación dialectal 'estrita' (diatópica) adoita ser menos marcada nos primeiros, en troca, a variación social/funcional acostuma resultar moito máis ampla nas cidades que non nas vilas e aldeas.

Endebén, acontece que no caso da estratificación social carecemos de tal definición previa das variables estra-lingüísticas, o cal é unha fonte de dificultades: para operar con esta noción é imprescindible posuír unha idea clara da estrutura de cada sociedade, o problema é que entre os sociólogos existe escaso acordo a respecto desta cuestión fundamental (Berruto 1980 e 1995: 119-46). Por iso, paradoxalmente, a noción de 'sociolecto' está lonxe de ocupar un lugar central na teoría sociolingüística. Os factores aos que se adoita outorgar maior peso na definición do estatus social son a ocupación, a renda, o nivel educativo e a residencia; adicionalmente, tamén se pode considerar a orixe familiar e/ou a profesión dos proxenitores, entre outros factores $^{38}$; como noción máis complexa e abranxente tense proposto a de

38 Algúns sociólogos distinguen entre os estatus de adscrición ou 'de partida' (pertenza relixiosa ou étnica, de casta, sexo ou familia) e o de 'logro' ou 'de chegada' (educación, renda, ocupación). 
'estilo de vida' (Berruto 1995: 127). Aínda que a correlación entre as variables antes citadas adoita ser estreita (unha profesión de prestixio adoita esixir un alto nivel educativo que só está ao acado dos descendentes de familias con ingresos elevados, que por vía da regra habitan nas cidades ou os seus arredores), o certo é cada unha delas delimita grupos sociais parcialmente distintos; por parte, varias das ditas distincións téñense revelado escasamente operativas para a sociolingüística.

Por tanto, podemos preguntarnos ¿existe unha única xerarquía ou cando menos unha xerarquía 'fundamental' para cada sociedade? Ou a estratificación social é un termo vago que abrangue un abano de diversas estruturas xerárquicas frouxamente interrelacionadas? Os estudos dispoñibles ofrecen relativamente pouca base para a noción do estatus como fenómeno unitario. As sociedades contemporáneas presentan unha estrutura moi complexa e matizada, en razón da mobilidade do corpo social: analogamente ao que acontece coas variedades lingüísticas, é practicamente imposible efectuar unha división nidia dunha sociedade nun pequeno número de clases ben definidas, pois os grupos de estatus forman un continuum gradual, en que ademais se atravesan e solapan os diversos criterios que antes indicamos.

Aínda así, coidamos que as observacións que antes desenvolvemos acerca da definición das variedades lingüísticas (e as linguas) son de aplicación ao caso: os actores sociais recoñecen estratos sociais (probablemente como consecuencia de estereotipacións), e por outra banda é posible dexergalos con criterios obxectivos. É certo que uns e outros agrupamentos non coinciden completamente, tamén o é que non existen fronteiras tallantes, pero isto non converte tales clasificacións en arbitrarias; no entanto, resultan de grande utilidade tanto para guiar o comportamento dos axentes coma para explicar a estrutura e dinámica sociolingüística das comunidades. Para máis, resulta que a variación lingüistica é unha variable que os propios actores utilizan frecuentemente (en combinación con outras) á hora de establecer as categorías sociais (o cal, por certo, fai aínda máis insostenible a posición dos sociólogos que ignoran esta variable).

Unha observación incidental: neste asunto discrepamos con Coseriu cando clasifica no eixo diafásico a variación relacionada co xénero-sexo (home/ muller) e os grupos etarios (infancia/ mocidade/ madurez/ ancianidade). Estas variables responden claramente a categorías sociais, non, como afirma este autor, biolóxicas: está claro que os grupos de xénero ou idade, aínda 
que teñen unha obvia base biolóxica, constitúen construtos socioculturais. Pola contra, coidamos que os denominados tecnolectos, 'linguaxes de especialidade' ou 'variedades especializadas', como nós preferimos denominalas (e onde incluímos os argots e as xergas; abreviaremos VES) son máis ben variedades diafásicas que non, como quere Coseriu, diastráticas, pois o seu uso depende de factores contextuais ${ }^{39}$. En todo caso, tampouco as VES nos van ocupar aquí.

Sexa como for, para identificar, caracterizar e clasificar os sociolectos en calquera comunidade lingüística, parece imprescindible ter unha idea previa de cales son as variables sociais coas que imos tentar correlacionar as variables lingüísticas en aprezo, e unha cuestión tan complexa non pode despacharse cunha rápidas pinceladas impresionistas ${ }^{40}$. O risco de deixarse levar pola intuición neste terreo xa o sinalou, coa súa agudeza habitual, P. Bourdieu:

Tanto en canto ignoren o límite que é constitutivo da súa ciencia, aos lingüistas non lles queda outra que procuraren desesperadamente na lingua o que en realidade está inscrito nas relacións sociais en que esta funciona, ou ben facer socioloxía sen se decatar, ou sexa, a risco de descubriren na propia gramática o que a socioloxía espontánea do lingüista importou nela de xeito inconsciente (1982: 14-15).

Sen contradicir o sociólogo francés, podía respondérselle, na liña que deixamos apuntado, que moitas das dificultades para elaborar unha teoría sociolingüística sólida derivan do feito de que os sociólogos acostuman dar a lingua por suposta e non a consideran un obxecto problemático; pero aínda por riba, tampouco non ofrecen unha teoría sociolóxica en que se poida estear unha teoría do uso lingüístico (Coulmas 1996: 5). No entanto, todos os

\footnotetext{
39 A linguaxe técnica especializada dunha profesión ou dominio do coñecemento non constitúe unha variedade 'fundamental' para os seus usuarios, que só a empregarán nos contextos aquecentes.

${ }^{40}$ Véxase Dubert 2002: 16. É certo que, tal como sinala este autor no lugar indicado, un dialectólogo non está comprometido a estudar a realidade xeográfica que el fai correlacionar cos datos lingüísticos que analiza, pero un dialectólogo non pode facer dialectoloxía sen ter previamente un 'mapa' claro do territorio: non se admitiría nun dialectólogo a aseveración de que 'lle dá a impresión" de que Fisterra cae no occidente de Galicia, e que "ten entendido" que este sector do territorio galego é fronteirizo con Portugal. Por razóns análogas, non se pode facer sociolectoloxía sen apoiarse nunha visión minimamente clara e obxectivamente contrastable da estrutura da sociedade galega. Naturalmente, o sociolingüista ou sociolectólogo non se ocupa de estudar e definir tal estrutura, como o dialectólogo non se encarga de tracexar mapas, pero debe dispor deles.
} 
falantes teñen consciencia en graos diversos do fenómeno da variación e son capaces de identificar o seu valor social, de aí que exista un xuízo consensual sobre os usos lingüísticos, tanto os valorizados canto os desvalorizados (Jollin-Bertocchi 2003: 30). Cara a isto mesmo apunta Labov: "as actitudes sociais ante a lingua son extremadamente uniformes no interior dunha comunidade lingüística [...] o correlato da estratificación regular dunha variable sociolingüística no plano do comportamento é o acordo uniforme no plano das reaccións subxectivas a respecto de tal variable" ${ }^{41}$.

Algúns autores procuraron unha saída da dificultade mediante o recurso a unha sociolingüística 'interpretativa': "un traballo que comeza pola observación do desempeño lingüístico e interprétao en termos de significado social; no canto de comezar pola estrutura social e procurar os seus correlatos lingüísticos" (Le Page 1996: 31). A isto, poderíamos opoñer, na liña de M. A. K. Hallliday (1978: 34-5): "hai unha diferenza entre o 'social' e o 'sociolóxico': se describimos un contexto de situación en termos de observacións ad hoc acerca dos escenarios en que se usa a lingua, isto pode ser cualificado como unha achega 'social' á lingua, pero dificilmente como unha achega 'sociolóxica'; para o segundo sería precisa unha teoría da estrutura e o cambio sociais". ¿Debemos conformarmos cunha achega 'social' (fundada nas percepcións dos propios locutores), e renunciar, cando menos de momento, á achega sociolóxica? Velaí o dilema entre a sociolingüística correlacional e a interaccionista, ao que xa nos referimos antes neste artigo.

A proposta de Hudson (1996: 187), na liña do apuntado canto á variación lingüística, pode permitir avanzar un pouco no camiño da identificación dos grupos sociais: "A noción de grupos sociais discretos é menos iluminadora que a visión da sociedade organizada arradedor dunha serie de diferentes puntos focais, cada un dos cales define unha norma separada de conduta [incluíndo o aspecto lingüístico-comunicativo] e atrae, en graos variables, a lealdade de certos membros da sociedade". A partir de aí, Hudson estéase na teoría de LePage sobre os 'actos de identidade' (LePage / Tabouret-Keller 1985: 180-86). Segundo esta, tanto os grupos sociais canto as propiedades lingüísticas que a estes se atribúen son perceptos de cada individuo en boa parte idiosincráticos, aínda que contrinxidos por realidades obxectivas. Os grupos fórmanse mediante actos de proxección e focalización, non necesariamente conscientes ou racionais. As 'explicacións' residen nas complexas

\footnotetext{
${ }^{41}$ Labov 1983: 312. Porén, o presunto carácter consensual destes xuízos foi fundadamente contestado por outros sociolingüistas, que salientan as tensións e conflitos que atravesan as comunidades lingüísticas (Milroy / Milroy 1997: 52-53).
} 
motivacións psicolóxicas dos individuos, condicionados por factores sociais. Destarte, os grupos sociais relevantes son os que o individuo percibe como tales, que non necesariamente cadran cos que o sociolingüista establece segundo métodos obxectivos. Cada individuo crea os sistemas do seu comportamento lingüístico con tal de que se asemelle ao do grupo ou grupos con que el, dependendo da ocasión, desexa ser identificado, na medida en que:

a) pode identificar os grupos,

b) ten a oportunidade e a capacidade de observar e analizar os sistemas de conduta destes,

c) posúe unha motivación dabondo forte que o impulsa a escoller e a adaptar o seu comportamento en consecuencia,

d) ten capacidade abonda para adaptar o seu comportamento no senso desexado.

Para axeitar o seu comportamento, o individuo precisa experimentar unha duradeira exposición á variedade lingüística correspondente, posuír a suficiente destreza lingüística para incorporala ao propio repertorio e estar disposto a identificarse coa clase de persoa que a usa. Segundo LePage, todos somos 'camaleóns lingüísticos', modulamos o noso discurso dependendo da identidade que queremos proxectar en cada ocasión particular.

Coidamos que este modelo de desempeño lingüístico é moi acaído para explicar os fenómenos de cambio de lingua que se verifican en procesos de substitución/ retención lingüística coma o galego, aínda que se cadra resulta excesivamente indeterminada á hora de conceptualizar operativamente o repertorio lingüístico da comunidade (véxase o dito antes). Seguimos mantendo que non se pode prescindir das nocións de 'variedade' nin de 'estrato social', a risco de atomizar indefinidamente a realidade sociolingüística e bloquear calquera posibilidade de análise teórica e a grande escala. Por caso, a investigación en socioloxía da lingua realizada ata a actualidade mostra contundentemente que á hora de determinar a distribución social do galego e o castelán as variables xénero, idade, hábitat, nivel de estudos e tipo de ocupación-categoría profesional constitúen discriminantes de indubidable relevancia. Non vemos por que razón esas mesmas variables non van ser tamén pertinentes á hora de estudar a variación lingüística. Recoñecendo que a variable 'estrato social' é a de definición e manexo máis complexo, coidamos que se pode facer operativa utilizando como categoría de referencia a ocupación- categoría profesional, e combinándoa co nivel de estudos, que resulta dunha relevancia obvia cando atendemos ao aspecto lingüístico. 


\section{A CUESTIÓN DO 'ACENTO'}

No plano do coñecemento común dos locutores, un dos marcadores máis importantes do sociodialecto básico do falante é o 'acento', unha percepto borroso en que se funden un conxunto bastante heteroxéneo de fenómenos sonoros: variables propiamente fonéticas (coma, no galego, gheada, distintos tipos de seseo, ou timbre, duración e intensidade de certas vogais) e trazos prosódicos como a entoación, xuntamente con riscos paralingüísticos como a velocidade de dición ou a cualidade da voz. É de salientar que un aspecto coma este, relativamente periférico desde o punto de vista da estrutura lingüística, resulte ter unha especial relevancia na percepción e categorización dos falantes, os cales extraen del unha 'información' moi significativa sobre a identidade social do locutor. Será de interese referirnos aquí a unha recente investigación do Seminario de Sociolingüística da Real Academia Galega ${ }^{42}$, en que se utilizaba a técnica das máscaras (matched-guise technique) para explorar as actitudes lingüísticas da mocidade galega, e na que se manexaba a variable 'lingua' combinada coa variable 'acento' (castelán con acento castelán / castelán con acento galego / galego con acento castelán / galego con acento galego). O devandito estudo chega á conclusión, solidamente apoiada na investigación empírica, de que

a variable 'lingua da máscara' non inflúe por si mesma nas puntuacións adxudicadas ás variedades lingüísticas. [...] A ausencia de acento galego (e presencia de acento castelán) determina case exclusivamente a percepción que teñen os rapaces [enquisados] do falante [...] En definitiva, neste sector da poboación atópanse fortes prexuízos asociados ós trazos fonéticos e prosódicos do galego. Os devanditos prexuízos refírense fundamentalmente á dimensión de 'competencia-status social' [...] Os resultados obtidos indican que a base sobre a que se establecen os procesos de categorización social dos falantes nun contexto de uso público da lingua está configurada polo acento galego e polo sexo das máscaras (RAG 2004: 37 e 68).

Coidamos que os achados deste traballo botan luz sobre os debates acerca do '(neo)galego urbano' a que antes nos referimos de pasada. Secomasí, sospeitamos que por debaixo das valoracións aparentemente consensuais do acento sinaladas polos estudosos ("tamén se confirma para esta mostra a ausencia de influxo de variables sociodemográficas e sociolingüísticas nas valoracións actitudinais", ibidem), que van ao encontro da posición "conse-

42 Casares Berg et alii 2003: 19-70; véxase tamén Casares Berg / Fernández Salgado / Loredo Gutiérrez / Suárez Fernández 2003. 
sualista' de Labov, subxacen esquemas de valoración contrapostos entre os galego-falantes e os castelan-falantes, que quizais se poderían elicitar mediante outro tipo de procedementos de investigación. Cara a isto, na liña de Milroy/ Milroy a que no referimos atrás, apunta un estudo realizado entre alumnos de ensino medio en Ourense hai uns quince anos, que detectaba tres grupos sociolingüísticos (tocante ás actitudes) ben caracterizados, galego-falantes rurais, galego-falantes urbanos e castelán-falantes urbanos:

Os primeiros amosan unha boa disposición cara ó seu propio grupo e unha alta valoración tanto do galego coma do castelán. Os segundos, aínda que recoñecen a importancia do castelán, son máis críticos cos comportamentos asimilacionistas. Pola súa parte, os castelán-falantes urbanos teñen unha alta estima do seu grupo, e sobre todo, dos galego-falantes; actitudes moi positivas que, sen embargo, non se manifestan coa mesma intensidade cara ó uso da lingua galega (Carballeira Anllo et alii 1994: 17).

Estamos ante dúas cuestións en que convirá aprofundar mediante a realización de novas pescudas de campo.

\section{DA NORMA AO USO}

\section{SOCIO-ESTILO, ESTÁNDAR E NIVEL}

Á hora de trataren dos 'niveis de lingua', a maioría dos estudosos operan non con variables estritamente sociais, mais cun híbrido de variables sociais e funcionais, nos seguintes termos: (a) os sociolectos superiores aparecen representados por un rexistro elevado ('esmerado' e/ou 'impersoal'); (b) os sociolectos medios por rexistros medios ('impersoal' e 'coloquial'); e (c) os sociolectos inferiores por rexistros baixos ('familiar' e incluso 'alternativo'). É como se a cada sociolecto correspondese un estilo 'cardinal', que sería o máis representativo del. O certo é que tal asociación -case sempre implícita, mesmo inconsciente, que probablemente responda a un proceso de estereotipación social- presenta unha imaxe distorcida da realidade, pois o lóxico sería comparar os tres sociolectos nun mesmo estilo (por caso, o coloquial). O que acontece é que en termos tanto de representación social coma de análise académica, unha asociación disimétrica coma a anterior presenta a avantaxe de que produce prototipos de variedades claramente distintos entre si, subliñando as diferenzas e reforzando os contrastes entre elas. 
Pero hai máis. Cando se trata de niveis de lingua, adóitase operar con entidades aínda máis complexas, definidas non só nas dimensións social e funcional, mais tamén en termos de conformidade/ desviación con respecto ao 'estándar', segundo un criterio moi corrente entre os estudosos que traballan sobre idiomas 'normalizados' (o cal, no aspecto propiamente lingüístico significa, precisamente, idiomas plenamente estandarizados) ${ }^{43}$. Por caso, Jollin-Bertocchi (2003: 37-41), que ofrece un tratamento paradigmático desta cuestión nun idioma arquetípico, o francés, sostén que o termo 'nivel de lingua' expresa a organización ideolóxica da lingua en usos 'baixos' e 'elevados', e esta noción se aplica "moi exactamente" ás variacións segundo a clase social. En consecuencia, distingue tres niveis, un intermedio, normativo ou neutro, outro supernormativo (français cultivé) e outro subnormativo (français populaire). Daquela, do que se nos está a falar non é dos principais 'socio-estilos', mais dunha noción aínda máis ampla.

Xa que logo, a noción de 'niveis de lingua' á derradeira remite a un esquema simplificado da arquitectura global do sistema, unha visión sincrética desta, unha especie de síntese panóptica en que se combinan dúas dimensións diferentes, a funcional e a social, e dúas perspectivas, a descritiva e a prescritiva. Canto a isto último, aparentemente, cando falamos de 'estándar' non estamos a referirnos á estratificación social da lingua, mais a unha perspectiva diferente sobre a variación lingüística, relativa á codificación e á prescrición. O que acontece na realidade é que o código normativo adoita descansar na regulación metódica e pautada dun sociolecto de prestixio, máis precisamente do estilo 'cardinal' (medio-alto) dese sociolecto -mellor aínda, dunha versión idealizada desa variedade, tal como mostraremos máis adiante.

A base do estándar-código normativo é unha variedade lingüística asociada a usos e usuarios privilexiados, que ademais, acostuma ser adoptada por este grupo de estatus como emblema distintivo da súa posición hexemónica. Por riba, pode acontecer que o dominio deste código estea franqueado exclusivamente (ou case) a ese mesmo grupo, e se atope coutado máis ou menos severamente aos outros grupos sociais. Nestas circuntancias, o termo 'estándar' case inevitablemente comporta unha forte connotación social, ou, remite directamente a un sociolecto ${ }^{44}$. Os casos do francés e o inglés corresponden historicamente a esas tres condicións, aínda que en tempos recentes

\footnotetext{
43 A xeito de exemplo, véxase Trudgill (1983: 186-200) para o inglés.

44 "Entre nosaltres, com en totes les cultures occidentals, l'standard proposat, a l'igual que la normativa literària, arrenca d'uns presupòsits d'hegemonia històrica de la classe burguesa, la qual protagonitzà la reivindicació política i cultural arreu" (López del Castillo 1984: 28).
} 
o estándar democratizouse, e o acceso a el, vía sistema educativo, se encontra ao acado de todos os grupos sociais.

O caso do galego non é tan así, como tampouco o son o do alemán e o italiano, por citar outros idiomas que se apartan dese modelo. En galego, o estándar ten unha base polidialectal, seleccionada e elevada mediante un proceso de adopción, o que implica que, de comezo, carecía de falantes nativos: nestas condicións, o código normativo realízase inicialmente nos rexistros formais da lingua (ou máis ben como 'base común' aos rexistros formais, especialmente da escrita $)^{45}$. Así e todo, sucede que o seu uso como variedade formal (non 'nativa') está inicialmente limitado a un sector social determinado, de tamaño reducido (un grupo de elite socio-cultural): destarte, o que para este grupo constitúe variación diafásica (de rexistro) pode ser interpretada por outros grupos como variación diastrática (de sociolecto). Na actualidade, o que está a acontecer é que esta variedade comeza a ser adoptada como vernácula (variedade de instalación e nativa, transmitida interxeneracionalmente por vía familiar) por parte dun certo sector da sociedade, e deste xeito vai reforzándose a asociación con este.

Como corolario do dito, será conveniente introducir algunha aclaración sobre o que se entende por 'estándar', pois este termo engloba varias nocións moi próximas que neste lugar cómpre matizar: a) o código normativo; b) a variedade modelo ou exemplar, definida tamén, simultaneamente, nos eixos social e no estilístico; c) e finalmente, o lecto 'axial' da lingua (o 'axiolecto', se se nos permite), un subsistema de variedades sociais e estilísticas neutro desde o punto de vista da variación diatópica. Na primeira acepción, a idea de estándar remite non tanto a unha variedade lingüística en senso estrito, canto a unha matriz en que se atopan definidas (por vía da regra nun nivel decrecente de rixidez) e fixadas unha serie de variables morfosintácticas, fónico-gráficas e léxicas, que en conxunto forman o armazón elemental dunha gramática completa, da lingua falada e mais da escrita; adoito con especial énfase precisamente nos aspectos máis variables (onde aparecen con máis frecuencia os 'desvíos' e 'incorreccións'). Trátase dunha especie de módulo apto para o desenvolvemento dunha serie virtualmente indefinida de variedades, un formato nuclear que é posible despregar en varios sentidos. Cando falamos de 'estándar' neste senso, situámonos na perspectiva da codificación e a prescrición.

Como dixemos, o estándar-código ten a súa base en e serve de base para un conxunto de variedades socioestilísticas 'cardinais' que o materializan do xeito máis fiel, consideradas modélicas ou de referencia; en virtude preci-

\footnotetext{
45 Véxase para isto Lamuela / Monteagudo 1996: 260-63.
} 
samente da codificación e mais da súa asociación a usuarios, textos e contextos prestixiosos.

Entre as variedades socio-estilísticas, as mellores candidatas para tornárense base do estándar son dúas: o rexistro 'esmerado' do sociolecto superior e o rexistro 'impersoal' do sociolecto medio; cara a eles apuntan os nosos termos de 'variedade exemplar' e 'variedade común', respectivamente. Para algúns autores a clave da bóveda estaría representada pola segunda variedade: "o termo medio de todos aqueles niveis que convén propor como norma do uso falado para todos" (López del Castillo 1984: 28; algo similar vai implícita na proposta de Jollin-Bertocchi a que acabamos de referirnos).

Aínda que o estándar por unhas razóns ou por outras se atope vencellado a un nivel socio-funcional medio-alto, así e todo, pola propia lóxica das dinámicas sociolingüísticas ${ }^{46}$, en condicións normais máis cedo ou máis tarde acaba espallándose a grupos sociais inferiores e alargándose nun abano máis ou menos dilatado de estilos. Destarte, acaba por xerarse unha escala completa de variedades socioestilísticas labradas cun menor ou maior grao de fidelidade conforme o formato do estándar-normativo. Tal conxunto de variedades é central e neutro (no senso de que non se atopa marcado desde o punto de vista da variación diatópica), e constitúe o espiñazo da lingua, a súa columna vertebral. Neste último senso, o 'estándar' é un dialecto feito e dereito, só que un dialecto moi especial, pois ten carácter 'supradialectal' ou mellor, 'transdialectal': constitúese no que antes denominamos o 'axiolecto'.

\section{SOCIOLECTO E INTERLECTO: ARQUITECTURA DA LINGUA GALEGA}

Ao comezo deste artigo falamos de relativismo sociolingüístico. Unha boa mostra deste fenómeno constitúeo o tipo de análise da variación sociolingüística en Galicia que se veu desenvolvendo ata a data, que non tomou como referencia principal o estándar (pois tal cousa non existiu ata data recente en galego), mais a variación diaglósica ou, o que é o mesmo, intersistemática ${ }^{47}$. A razón disto é que, como dixemos, o eixo organizador da variación sociolingüística en Galicia é a diglosia galego/ castelán, á que vai intimamente vencellada o fenómeno da interpenetración mutua das linguas,

\footnotetext{
46 Véxase o dito antes con respecto aos actos de identidade, e tamén o que expoñemos máis adiante verbo dos procesos de asimilación / substitución.

${ }^{47}$ Niso coinciden, con matices, Álvarez Cáccamo 1989: 278-88; Monteagudo / Santamarina 1993: 144-51; e Dubert 2002, a pesar das diferenzas noutros aspectos dos respectivos traballos. Aproveitamos para deixar aquí constancia de que o segundo artigo, aínda que publicado en 1993, foi redactado e entregado para a súa publicación en 1989.
} 
un fenómeno reforzado pola extensión crecente do bilingüismo ${ }^{48}$. Obviamente, na dita situación é posible caracterizar os sociolectos con respecto ao maior/ menor grao de interinfluencia que presentan, e identificar 'interlectos' situados nalgún punto do gradatum multidimensional polarizado entre o galego e o castelán ${ }^{49}$; ou, máis precisamente, entre o galego estándar (ou a súa realización concreta, o galego exemplar, que así e todo resulta unha entidade de carácter ideal) e o castelán estándar (ou a súa concreción material, o castelán exemplar). No interior de tal escala espazo atópanse mergulladas boa parte das producións lingüísticas que se realizan nas interaccións entre os membros da comunidade lingüística galega ${ }^{50}$.

Dentro do dito gradatum interlectal coidamos que é factible, e mesmo adecuado, distinguir variedades relativamente definidas e estables, doutras moito máis difusas e volátiles ${ }^{51}$. Como o concepto de variedade interlectal inestable foi posto en cuestión (Dubert 2002: 18-19), volvo sobre el, reafirmándome na súa pertinencia: os bilingües esporádicos e/ou con competencia precaria nunha lingua secundaria (ás veces trátase de persoas de lingua inicial distinta á habitual) teñen tendencia a construír ou botar man de modalidades convenientemente simplificadas ou adaptadas desta. É de aí de onde xorden os interlectos inestables: modalidades fortemente galeguizadas do castelán rexional (castrapo) e severamente castelanizadas de galego popular (chapurreado). Tanto as primeiras coma as segundas poden vernacularizarse (tornarse 'linguas de instalación' e incluso 'linguas iniciais' para algúns falantes), e converterse no que Dubert acertadamente denomina 'interlinguas fosilizadas' (2002: 23); aínda neste caso, continúan caracterizándose pola súa extrema fluidez e difusividade. Advertimos que non deben confundirse as anteriores coas variedades 'adxacentes', que máis abaixo denominamos 'castelán galeguizado' e 'galego castelanizado' (sobreenténdase nos dous casos o adverbio fortemente), que son modalidades plenamente vernáculas e considerablemente máis estables.

Por parte, a situación sociolingüística de Galicia caracterízase dunhas décadas a esta parte por un dinamismo impresionante: non se trata dunha evo-

\footnotetext{
${ }^{48}$ Véxase, a título ilustrativo, os datos do Mapa Sociolingüístico de Galicia no tocante á lingua habitual do entrevistado segundo o nivel de estudos e segundo a clase social (RAG 1995: 56 e 59).

${ }^{49}$ Lembremos que esta imaxe contraponse á do continuum en escala implicacional (aínda que unha parte dos fenómenos adoptan, efectivamente, unha configuración escalar implicacional).

${ }^{50}$ Unha comunidade bilingüe/ diglósica, que quizais está comezando a escindirse en dúas, pero este é outro asunto do que non imos ocuparnos.

${ }^{51}$ Sempre tendo en conta que nas condicións de contacto lingüístico a difusividade tende a ser máis intensa, mentres que nas de de monolingüismo a tendencia é a unha maior focalización, de xeito que, por vía da regra, nas primeiras as variedades tenden a ser menos definidas estables ca nas segundas.
} 
lución a paso lixeiro, trátase propiamente dunha conxuntura crítica, se cadra, dunha auténtica catástrofe. Empregamos este último termo á mantenta, cunha intención puramente descritiva, desprovisto de calquera connotación expresiva -en particular do seu aparente dramatismo. Referímonos a un modelo de evolución (socio)lingüística que non descansa na noción tradicional dun progreso lineal e un avance paseniño a ritmo constante, mais que recoñece a importancia crucial dos períodos de turbulencia, de aceleración brusca, de acumulación exponencial e precipitación repentina dunha serie de mutacións de distinto carácter, en que os parámetros ecolóxicos dunha lingua (ou se se quere, as condicións socio-históricas básicas da súa comunidade falante) experimentan unhas mudanzas drásticas, incontrolables, que impulsan e á vez son impulsados por transformacións radicais da cultura e a consciencia metalingüistica da comunidade, e que conducen a disgregacións caóticas e reconfiguracións inopinadas de distintas parcelas do sistema lingüístico e mesmo do propio sistema canto tal ${ }^{52}$.

A dinámica do contacto de linguas realízase por dúas vías, non incompatibles mais complementarias: a substitución e a asimilación. A substitución consiste no cambio de lingua, a asimilación é produto da atracción dunha lingua sobre outra, e consiste na progresiva aproximación das formas e estruturas da segunda cara á primeira. A substitución habitualmente implica non o abandono súpeto e radical da lingua propia e a adopción igualmente instantánea e completa da lingua allea (isto si pode darse no caso da transmisión interxeneracional), mais a adopción da segunda en certos contextos de uso, e no seu caso, a gradual extensión destes contextos e finalmente a adopción desta como 'lingua de instalación' (o que raramente implica a monolingualización total nesta).

A asimilación implica a incrustación e adaptación de formas e estruturas dunha lingua-fonte noutra lingua-meta, por diversas vías: dunha banda, por razón de economía de esforzo de aprendizaxe e actuación (performance), os bilingües habituais tenden a fusionar canto posible as dúas linguas que empregan habitualmente, tomando como base a súa competencia na lingua primaria (inicial ou dominante) pero incorporando a esta certos elementos e estruturas da lingua secundaria (ou auxiliar); doutra banda, os bilingües transeúntes (que mudan de lingua de 'instalación' ou principal) arrastran á súa nova lingua 'principal' elementos da súa lingua primeira; finalmente, monolingües en cada unha das dúas linguas, en condicións de estreita convivencia e de presenza ambiental forte de ambas, incorporan elementos dunha na outra.

\footnotetext{
52 Véxase sobre a noción de 'catástrofe' aplicada á historia da lingua López García 1996 e 2000: $44-48$.
} 
Diversos estudos suxiren que no tocante á lingua, a sociedade non se atopa necesariamente polarizada entre 'arriba' e 'abaixo'; poden existir distintas pautas contraditorias, orixinadas en distintos grupos sociais, e incluso os que marcan a pauta non son necesariamente os grupos extremos (na cima ou no cabo), tamén poden selo grupos intermedios. En palabras de Labov, "o estudo dos cambios fonéticos actuais móstranos que unha innovación lingüística pode iniciarse nun grupo particular e desenvolverse fóra del, e que este desenvolvemento é normal; e tamén que ese grupo pode ser o de maior estatus, pero non é preciso e nin sequera frecuente que o sexa" (1983: 355). Temos razóns para acautelarnos contra unha visión mecánica da realidade lingüística en termos do modelo implicacional, como se existise un continuum polilectal que, tal escaleira mecánica, se movese continuamente desde o galego vernáculo cara ao castelán estandarizado das clases medias urbanas, un modelo que implica que todas as innovacións lingüísticas proceden sempre do mesmo punto (o castelán) e avanzan na mesma dirección (daquel cara ao galego). Esta visión estéase nun presuposto demostradamente falso: frecuentemente se dá o caso de que as mudanzas en variedades 'altas' se moven en dirección contraria a outras mudanzas en variedades máis 'baixas', e xa que logo unha destas variedades poden finalmente atraer a outra ou ben orientárense entrambas cara á diverxencia e á fragmentación.

Así, no medio das turbulencias que están a experimentar a sociedade e a lingua galegas neste período, dunha banda pugna por estabilizarse e establecerse (a redundancia é só aparente) un galego estándar que a duras penas consegue atinxir a condición de plenamente 'codificado', que se concreta na fala non tanto nun galego exemplar (ideal máis ca efectivo), coma nun galego 'común' para-estándar, flexible e discretamente diverso. Doutra banda, xorde como novidade o fenómeno do denominado 'neo-galego urbano' (quizais sería máis exacto denominado 'para-galego'), que tanta preocupación ten suscitado. En realidade, o 'neo-galego urbano' é o correlato elevado do galego chapurreado: ambas e dúas son variedades interlectais de carácter oportunista, producidas por castelán-falantes que se senten motivados para falar galego só ocasionalmente. A diferenza entre o 'chapurreado' e o 'neogalego' radica en que o primeiro resulta máis neboento e volátil ca o segundo, dado que precisamente este se emprega en funcións socio-comunicativas 'altas' (mesmo se escribe) e está orientado cara ao estándar.

O atranco que representa tal neo-galego cara á estandarización dun galego 'auténtico' non radica na súa mera existencia - esta mesmo pode considerarse un síntoma positivo dunha crecente presión social a favor do galego, dunha orientación cara a esta lingua de sectores previamente castelanófonos-, mais na súa tendencia a estabilizarse e a solapar o 'galego exemplar auténtico', interferindo a irradiación deste e incluso constituíndose en varie- 
dade de prestixio e referencia (mesmo para os galego-falantes), con perigo de que consiga suplantar aquel.

En definitiva, o espazo lingüístico galego, de carácter composto, estaría configurado polas seguintes variedades básicas:

a) Castelán exemplar, pautado polo castelán estándar, propio das clases altas e medio-altas urbanas, xeralmente monolingües e dotadas dun nivel elevado ou medio-elevado de instrución; atópase en proceso de expansión, atinxindo as camadas mozas das clases medias e mediobaixas das principais cidades.

b) Castelán rexional, con modulacións galegas, típico das clases mediobaixas urbanas e das camadas medias semiurbanas e rurais, cun nivel de instrución medio ou baixo, por vía da regra bilingües de dominancia castelá pero ás veces orixinariamente galego-falantes; dunha banda estase aproximando ao castelán exemplar, doutra está atraendo cara a si o castelán vulgar, tamén cede falantes ao galego común.

c) Castelán vulgar, marcadamente galeguizado, característico de sectores das clases populares (sobre todo urbanas e semi-urbanas) e das clases medio-baixas semiurbanas e rurais, carentes de ou con escasa instrución, xeralmente bilingües de dominancia galega; está recuando entre os grupos máis mozos perante o avance do castelán rexional.

d) Galego exemplar, a penas materializado, e máis na escrita do que na oralidade.

e) Galego común, medianamente depurado e uniforme, en proceso de consolidación, que aniña en franxas das clases medias urbanas e semi-urbanas, xeralmente cun nivel medio a alto de instrución, bilingües de dominancia galega ou monolingües galegos por elección; está avanzando lentamente a custa do castelán rexional e atraendo cara a si as outras variedades galegas.

f) Galego (popular) tradicional, con incrustacións castelás superficiais, asociado a sectores das clases populares semi-urbanas e en xeral ás camadas populares rurais, cun nivel baixo ou nulo de instrución, monolingües (por necesidade) ou bilingües de dominancia galega; dunha banda está a aproximarse ao castelán vulgar e rexional (deriva histórica) e doutra está experimentando o influxo do galego común (tendencia recente).

g) Galego popular (urbano), marcadamente castelanizado, característico das clases populares urbanas con escasa ou nula instrución e de sectores das clases medias semi-urbanas e rurais con instrución media ou baixa; habitual en falantes bilingües de dominancia galega ou de dominancia castelá pero de lingua inicial galega. A súa posición vese se- 
riamente erosionada pola forte competencia que sofre do castelán rexional e vulgar, e en moito menor medida, do galego común.

Aos anteriores sociolectos debemos engadir tres auténticos interlectos:

a) Castrapo, ou 'castelán intencional', variedade mixta producida por galego-falantes monolingües ou bilingües ocasionais, escasa ou nulamente instruídos.

b) Galego chapurreado, ou 'galego intencional', variedade mixta producida por castelán-falantes urbanos, monolingües ou bilingües ocasionais, cun nivel escaso ou nulo de instrución.

c) Para-galego ou neo-galego urbano, interlecto mixto producido por falantes iniciais do castelán exemplar ou rexional, cun nivel elevado de instrución, que conseguiron unha aprendizaxe defectuosa do galego; a categorización desta variedade é disputada: galego (incluso exemplar) para os seus locutores e para un sector da comunidade lingüística, castelán superficialmente galeguizado para outro sector da mesma.

\begin{tabular}{lc|r} 
castelán exemplar & neogalego urbano & galego exemplar \\
\hline castelán rexional & $\rightarrow$ galego chapurreado $\rightarrow$ & galego común \\
\hline castelán vulgar & $\leftarrow$ castrapo $\leftarrow$ & galego popular \\
& & galego tradicional
\end{tabular}

Táboa 4. Configuración do espazo lingüistico composto en Galicia.

O que acabamos de ofrecer é un cadro sumario, en trazos grosos, pero coidamos que pode dar unha idea aproximada da situación. Cumpriría caracterizar lingüisticamente cada unha das variedades, mediante trazos como o emprego correcto do pretérito perfecto (he dicho) no castelán exemplar fronte ao emprego exclusivo do pretérito indefinido (dije) nos casteláns rexional e vulgar, a alternancia na utilización das formas 'composta' e 'simple' do antepretérito do indicativo (había dicho / dijera) neste fronte ao uso exclusivo da segunda no castelán vulgar (dijera). Doutra banda, podíamos sinalar a distinción coidadosa das formas dixera (antepretérito de indicativo) dixese (pretérito de subxuntivo) no galego exemplar fronte ao uso estendido da primeira no galego común, que se volve practicamente exclusivo nos galego popular e tradicional (aínda que variedades deste conservan dixese polo menos nalgúns casos), e a utilización dos castelanismos habia dito e hei dito (ou tiña/ teño dito con valor equivalente), -entrambos ignorados nos galegos común, exemplar e tradicional-, respectivamente no galego popular (que alterna había dito co máis frecuente dixera) e o neogalego urbano (tiña dito/ hei teño dito por dixera/ dixen). De todos os xeitos, cómpre reali- 
zar un maior esforzo de investigación empírica neste terreo, que se atopa francamente desatendido ${ }^{53}$.

O galego tradicional (e en menor medida, o popular) caracterízase por unha grande variedade interna, que en boa parte se confunde coa variación diatópica: por tanto, nese nivel as dimensións da variación dialectal e sociolectal atópanse inextricablemente unidas. O mesmo non pode dicirse dos galegos común e exemplar, aínda que o primeiro tamén se atopa 'matizado' diatopicamente.

\section{NORMA OBXECTIVA E NORMA PRESCRITIVA}

Diciamos ao comezo da sección anterior que a sociolingüística veu a confirmar e explorar a heteroxeneidade constitutiva dos sistemas lingüísticos. Sinalemos agora que non se limitou a isto. Un dos obxectos de estudo aos que prestou máis atención foi a problemática da norma lingüística e das correspondentes actividades de codificación e prescrición, asuntos dos que a lingüística 'científica' contemporánea se tiña desentendido ${ }^{54}$. O concepto de norma, malia a súa aparente obviedade, non está libre de confusións; para simplificar, e no que nos interesa aquí, comezaremos por distinguir dous tipos de 'norma': a obxectiva e a prescritiva ${ }^{55}$. A distinción farase máis doada se reparamos en dous adxectivos derivados: normal, isto é, corrente ou rutineiro, un adxectivo descritivo que pode traducirse en termos de frecuencia estatística; fronte a normativo, isto é, conforme a unha regra, que equivale aproximadamente a 'prescrito'. En principio, unha variante normal nun (sub)sistema ou variedade lingüística é a que adoita aparecer nun texto producido nesa determinada variedade; sinxelamente, é frecuente nel, segundo un modelo probabilístico. Unha variante normativa é de uso preceptivo en determinados tipos de variedades, conforme un determinado código normativo. Tocante ao concepto de norma, temos, pois que distinguir a norma obxectiva da norma prescritiva. Vexamos.

a) Norma obxectiva ou norma usual (norme d'usage): todo (sub)sistema lingüístico defínese pola presenza, frecuencia e pautas de distribución (se-

$53 \mathrm{O}$ cal, por certo, non xustifica as imprecisións e erros de vulto (debidos en parte aos preconceptos do autor e noutra parte ao descoñecemento dos estudos dialectolóxicos galegos) que contén o por outra banda estimable artigo de Álvarez Cáccamo 1989.

${ }^{54}$ Para unha crítica desta posición, véxase en particular Trudgill 1984: 186-225; Milroy / Milroy 1985: 1-28; Daneš 1987; e Coulmas 1989.

55 En realidade, cada unha destas 'normas' é un conxunto coherente de 'normas' particulares, que rexen a distribución e estatus de cada serie de variantes. 
gundo certos parámetros sociolingüísticos) dun determinado conxunto de trazos; o que é o mesmo, por unha norma obxectiva inherente e constitutiva, que ten carácter implícito e que se manifesta no uso. Neste senso, pois, a noción de norma remite ao corrente, ao normal en senso cuantitativo e descritivo, ás pautas observables na actividade lingüística dun grupo ou nunha situación comunicativa determinados. Así pois, toda variedade lingüística está definida por unha norma inherente: o normal-obxectivo no meu dialecto (galego) de orixe é pronunciar [(scho] e non [( $\theta \varepsilon h o]$ ou [( $\theta \varepsilon$ yo], igualmente, a norma dese mesmo dialecto maniféstase na pronuncia ['m $\beta$ o] e exclúe a pronuncia ['mß o]; o mesmo acontece con [(diso] e [(sente] fronte a [(di Jo] e [( $\left.\int \varepsilon n t e\right]$, ti fixestes e non che vin fronte a ti fixeches e non te vin. Dito outramente, o meu dialecto orixinario é un (sub)sistema caracterizado precisamente por esas e outras variantes normais, e conxuntamente definen a súa norma obxectiva específica.

O lóxico, pois, desde o punto de vista descritivo é definir as variantes desde o punto de vista da súa frecuencia. Deste xeito, poderiamos distinguir os seguintes tipos de variantes: típica (frecuente), subtípica (menos frecuente) e atípica (insólita). Tamén aquí sería posible introducir distincións máis finas, se iso nos interesase, o que non é ocaso no presente contributo. Por vía de exemplo, comparando a frecuencia de variantes co-ocorrentes pódese falar de variantes co-frecuentes ou concorrentes (coa mesma frecuencia aproximada), variantes superfrecuentes e variantes subfrecuentes (as primeiras máis frecuentes entre outras, as segundas menos frecuentes ca outra ou outras). Se se desexa introducir a dimensión diacrónica, pode falarse de variantes conservadoras, neutras e innovadoras; ou regresivas (de frecuencia decrecente no tempo), estables (de frecuencia non variable no tempo) e progresivas (con frecuencia en aumento no tempo). Se se queren introducir matices de distribución nalgún dos eixos de variación, pódese falar de variantes marcadas (polo estilo, polo estrato social, etc.), fronte a variantes non marcadas. En todo caso, queda claro, que todas as variedades da lingua, precisamente por selo, teñen unha norma inherente, constitutiva, a norma obxectiva.

b) Norma prescritiva: esta noción implica a vixencia de determinados códigos de comportamento, entendidos como conxuntos de regras imperativas, instrucións e recomendacións contidas nun corpus metalingüístico (gramáticas, dicionarios, manuais e outros textos), por tanto, explícitas. É unha noción que remite ao normativo, o que se aconsella ou impón como 'correcto' - e correlativamente, o que recomenda como 'aconsellable' ou se tolera como 'admisible', ou ben o que se califica como 'desaconsellable' ou se refuga como 'incorrecto'- en nome dalgunha doutrina (no noso caso, dalgún 'ideal de lingua', do que falaremos a seguir) e/ ou autoridade. A norma des- 
critiva (o estándar-código) define a variedade padrón, ou sinxelamente o padrón lingüistico.

A vixencia dunha norma prescritiva implica a existencia dun dispositivo ideolóxico e dun aparello institucional socialmente recoñecidos, con autoridade para definir o que é correcto (lexítimo) e con capacidade para impor o seu criterio (Bartsch 1987: 133-49). A vixencia das prescricións lingüísticas fúndase máis ben no que en termos gramscianos podemos denominar hexemonía (dominio consentido) que non na coerción (dominación imposta e mantida pola forza). Isto significa que a vixencia da norma lingüística repousa nun consenso na avaliación das variantes e variedades no seo comunidade lingüística, un consenso que entre outras cousas se manifesta na asignación de sancións e recompensas simbólicas, outorgadas espontaneamente polos seus membos (xuízos implícitos ou explícitos, conscientes ou semiconscientes, do tipo que mal/ben fala fulano! ou Ben/mal dito!). Así e todo, non se pode esquecer que para a inculcación xeneralizada da norma lingüística (especialmente na escrita) é fundamental o papel de institucións formativas, nomeadamente o sistema educativo, cun aspecto coercitivo, expresado en premios / penalizacións prácticas (por caso, unha mellor/ peor nota nun exame a causa da ortografía).

En principio, as nocións de norma obxectiva e norma prescritiva semellan dabondo claras. Porén, en situacións de contacto lingüístico prolongado e íntimo, a cuestión complícase. Máis aínda, se, como acontece no caso galego, ese contacto se produce en condicións de disimetría, en dous sensos: (a) entre unha lingua dominante que monopolizou durante séculos a comunicación escrita e formal e unha lingua dominada reducida á comunicación oral e informal; e (b), posuíndo a primeira o seu propio centro de gravidade 'externo' á situación de contacto (isto é, o código normativo, variedades formais e o groso comunidade falante non afectados por esta), e véndose a segunda afectada de cheo por tal situación (co groso da comunidade falante exposta ao contacto, e carente de código normativo e variedades formais). Nas condicións devanditas, acontece que a norma obxectiva da lingua subordinada conterá numerosos elementos 'espurios', isto é, xeneticamente procedentes da lingua dominante.

Neste caso, os gramáticos dificilmente se poden contentar cunha simple descrición das normas obxectivas correspondentes ás variedades da lingua subalterna. Case inevitablemente terán que afrontar a tarefa de acertar cales variantes rexistradas na norma obxectiva son xenuínas e cales son espurias (pola súa orixe ou por resultaren de dinámicas externas á lingua subalterna ou dependentes da situación de contacto coa lingua dominante). Tarefa especialmente esgrevia, se, coma no noso caso, as dúas linguas son xenetica- 
mente próximas e estruturalmente semellantes, xa que isto pode agravar o sentimento de inseguranza lingüística nos só dos falantes, mais tamén dos lingüistas, que non poden descansar tranquilamente nos seus propios xuízos metalingüísticos, nin tampouco acudir a falantes e textos autorizados (libres de 'contaminación'). Aínda posteriormente, os prescritores deberán determinar cales deses elementos deben ser depurados e cales (se algún) deben ser incorporados á norma prescritiva. Tendo en conta esa situación, e o perigo resultante de fagocitación da lingua dominada mediante a súa disolución na dominante ou dialectalización por parte desta, o purismo lingüístico parece unha actitude racionalmente xustificada. Emporiso, é debatible é o grao desexable de intensidade de tal purismo: tornaremos sobre isto.

\section{DO PRESCRITIVISMO PREXUIZOSO AO NORMATIVISMO RACIONAL}

A prevalencia da variedade normativa esteouse tradicionalmente nunha ideoloxía prescritivista fondamente arraizada na cultura lingüística europea, con precedentes remotos xa en Grecia e Roma, e unha continuada elaboración desde o Renacemento. Desde esta ideoloxía, a lingua é concibida como unha entidade rixidamente xerarquizada, coroada pola variedade culta (conformada inicialmente pola escrita literaria e pola fala da corte rexia; máis tarde, segundo os gustos e os usos da alta burguesía urbana) e o código normativo emanado desta, que servían de padrón para medir e valorizar as variedades non padronizadas, consideradas como deturpacións daquela. O prescritivismo tradicional áchase vencellado á pervivencia de estruturas sociais e esquemas de valores autoritarios e discriminatorios, e descansa nunha manchea de preconceptos, que a final converten a variedade padrón nun elemento clave da hexemonía e do control en mans dun grupo de prestixio e a tornan nun pesado factor exclusión sociocultural. A lingüística científica, formalmente, mostrouse distante con respecto a esa ideoloxía prescritivista, pero renunciou a realizar unha crítica a fondo desta, e na práctica chegou a reforzala, contribuíndo deste xeito á súa perduración.

Endebén, nas últimas décadas está a xurdir un novo tipo de normativismo crítico e racional. Este normativismo, que funde as súas raíces na teoría da lingua estándar do Círculo Lingüístico de Praga, non nega a necesidade da regulación lingüística e incluso denuncia a negativa de certas teorías lingüísticas 'científicas' a trataren o problema (Monteagudo 1994, Daneš 1987). Esta nova visión procura unha xustificación enteiramente nova da prescrición lingüística, tentando comprometer os lingüistas no fomento dunha cultura lingüística desprexuizada e non asociada ao mantemento de relacións de dominación social, unha posición desde a cal os lingüistas non só non deben refugar a colabora- 
ción nas tarefas normativas, como teñen que colaborar nelas (nesta liña, ademais do xa citado Daneš 1987, entre outros, Coulmas 1989 e Bagno 2003).

Unha das tarefas máis relevantes da sociolingüística consistiu en fornecer ferramentas para a crítica do prescritivismo prexuizoso. Desta crítica derivouse unha relativización da importancia das variedades normativas e das ideoloxías prescritivistas, obstinadas en marxinar toda variante condenada e bloquear toda mudanza. As linguas xa non poden ser contempladas como entidades monolíticas e homoxéneas, das que as 'variedades padrón' serían os máis cualificados representantes -ou peor aínda, as súas formas acabadas-, mentres que as variantes e variedades non padronizadas constituirían 'erros', 'desvíos' ou 'anomalías'. Se os usos (normas obxectivas) varían, a norma varía ao mesmo tempo, e daquela pode definirse como 'uso non marcado en relación ao contexto dun dado enunciado'. Así, existirá non unha norma única, mais varias normas específicas segundo o contexto, o medio social, o lugar, o individuo.

Por outra banda, tende a doptarse unha visión máis abranxente, non exclusivamente desde a perspectiva parcial da variedade padrón, mais con pretensións pansistemáticas. Nesta perspectiva, a noción que corresponde á de corrección é a de 'adecuación', que nos permite falar de variantes apropiadas ou aptas, variantes tolerables, e variantes inapropiadas. Non se trata dun cambio de nomenclatura, pois agora trátase de lexitimar os xuízos de adecuación que van asociados á noción de norma obxectiva de cada estilo: por tanto, xa non se trata unicamente de que digamos que nun estilo formal é 'inapropiado' (no canto de 'incorrecto') empregar variantes non padronizadas. Trátase de que admitamos que, reciprocamente, nun estilo informal pode ser tamén 'inapropiado' empregar variantes normativas. Destarte, podemos dicir que para cada estilo de lingua existen variantes óptimas que son consideradas máis acaídas para o tal estilo, e non só outras subóptimas, tal como acontecería na perspectiva tradicional (se só era correcto o normativo, todo o incorrecto era, por definición, subóptimo), mais tamén superóptimas, isto, é 'excesivamente correctas'.

Así e todo, engánase quen pense que a sociolingüística derogou os estándares como entidades inútiles, opresivas e por tanto non lexitimadas, que denunciou as actividades de prescrición como globalmente nocivas ou irracionais, e que condenou as actitudes asociadas a aqueles e a estes. No que se esforzou foi en contribuír a relativizar a importancia dos primeiros, a reformular os fundamentos, métodos e obxectivos das segundas e a elucidar, peneirar e depurar as terceiras. De aí xorde un normativismo crítico e informado, esclarecido canto aos seus obxectivos e métodos de traballo, respectuoso coa diversidade lingüística, as identidades e as actitudes que se asocian con esta, promotor da tolerancia e da flexibilidade, e coidadoso non só 
de non asumir mais de combater os preconceptos, na procura dun tratamento equitativo e racional dos problemas.

Desde este normativismo ilustrado, saliéntase a importancia e utilidade da norma padrón como elemento de auto-regulación do sistema, como forza centrípeta no interior do vasto universo centrífugo de toda lingua humana, en especial para a práctica da escrita (Bartsch 1987: 141-49 e 227-93, Bartsch 2003). A función básica dun padrón de lingua é estimular, polo menos na escrita, unha relativa cohesión nun espazo sociocultural amplo e diversificado, e garantir unha base de comunicación entre as distintas variedades (históricas, xeográficas, sociais e funcionais). O emprego dese padrón xorde dun equilibrio dinámico consentido entre a liberdade / creatividade de cada falante e a necesidade de comunicar e integrarse socialmente. A vixencia do padrón impón unha certa estabilización da lingua, procurando controlar os efectos virtualmente desintegradores da variación e ralentizar o impacto potencialmente desestabilizador das mudanzas. O ideal do estándar sería, en palabras de Haugen, 'variación mínima da forma e máxima na función'. Os teóricos de Praga sinalaban como as súas características a estabilidade, a elasticidade, a polivalencia e o prestixio. En palabras de Renate Bartsch,

no tocante á preocupación pola corrección, esta é unha actitude necesaria, cargada de valor positivo e coherente cun trazo característico e común do estilo de vida dos humanos: o desexo de controlar as súas accións e produtos e de procurar os medios necesarios para garantir que os instrumentos lingüísticos de comunicación e interacción sexan amplamente recoñecibles e interpretables (2003: 30).

Esta mesma autora sinala que preocuparse polo que está ben e o que está mal, o que é correcto ou incorrecto, aceptado ou non aceptado, é unha base necesaria para todo comportamento humano, que as persoas queren controlar e do que queren responsabilizarse, e é unha condición previa para a comprensión: na interpretación do comportamento (lingüístico) sempre presupomos que os medios (lingüísticos) son correctamente empregados, mentres non houber indicación do contrario.

\section{A VARIEDAde PADRÓN, A VARIEDADE COMÚN E AS VARIEDADES VERNÁCULAS}

No apartado $₫ 1$ do presente traballo, ao fío do concepto de estandarización, introducimos unha distinción entre variedades vernáculas e variedades cultivadas. As primeiras, diciamos, serían nativas, as transmitidas e adquiridas pola xeneralidade dos falantes mediante socialización primaria; as segundas, as elaboradas, serían as transmitidas e aprendidas mediante sociali- 
zación secundaria. A análise desenvolvida no apartado $₫ 10$, co gallo das nocións de socio-estilo, estándar e nivel, permítenos agora afirmar que as variedades cultivadas son características dos 'niveis' altos (socialmente recoñecidos como tales), as variedades vernáculas son as características dos 'niveis' inferiores. Todas as linguas, en canto están vivas, posúen variedades vernáculas, que son as empregadas pola xeneralidade dos seus falantes nas situacións de comunicación máis habituais. Só as linguas que se atopan un estado máis avanzado de desenvolvemento -que corresponden ao seu uso en sociedades cun mínimo de complexidade-, se diversifican social e funcionalmente, e xeran variedades cultivadas. No caso das linguas que se despregaron na escrita, a diversificación de estilos adoita ser maior; dándose o caso de que a escrita require (e facilita) un grao maior de elaboración da lingua.

Como dixemos, o camiño que leva das variedades vernáculas ao padrón lingüístico é un camiño de ida e volta. A partir daquelas xéranse as variedades cultas ou exemplares, correspondentes aos estilos máis elevados, e estas serven de base para as variedades-padrón codificadas. A variedade padrón existe basicamente nunha forma codificada, pouco menos ca virtual. Pola súa banda, unha vez constituídas, as últimas inflúen sobre a variedade exemplar, que, de regra, representa a materialización efectiva do padrón lingüístico, aínda que raramente reflicte dunha forma fiel este, pois a variedade culta é máis flexible, e implica algún tipo de compromiso entre o padrón e as variedades vernáculas. Ese compromiso é aínda maior no caso do que podemos denominar 'variedade común', característica dos estilos semiformais, moito máis permeables ás variedades vernáculas.

En condicións lingüísticas normais, pois, existe unha interpenetración das distintas variedades lingüísticas, de maneira que o padrón, sempre artificial e cuase-virtual (excepto na escrita), se realiza nunha variedade exemplar (escrita e falada), aínda relativamente ríxida, que á súa vez inflúe en e déixase influír por unha variedade común moito máis flexible, versátil e permeable ás variedades vernáculas. Deste xeito, o influxo da variedade padrón chega, aínda que moi atenuado, ás variedades vernáculas. O proceso de constitución desas variedades padrón, exemplar e común é precisamente o que denominamos estandarización: o rótulo de estándar recobre estas tres variedades. Un estándar que existe só en forma de variedade padrón é un estándar artificial, alleo ás prácticas lingüísticas reais dos falantes. Un estándar que se materializa nunha variedade exemplar xa ten un carácter máis real, máis próximo á actuación efectiva dos falantes. Un estándar normal debe tamén apoiarse en e servirlle de orientación a unha variedade común, que é a verdadeiramente usual. En definitiva, podemos dicir que o padrón constitúe a norma prescritiva do estándar, a variedade exemplar constitúe a versión 'forte' da norma obxectiva do estándar, a variedade común constitúe a 
versión 'feble' da norma obxectiva do estándar (un 'para-estándar', podería dicirse) e as variedades vernáculas sitúanse no terreo do sub-estándar.

Non todos os falantes acceden á competencia lingüística plena na variedade exemplar, este acceso está máis ben reservado aos falantes instruídos, pertencentes á elite educada, que pode ser máis ou menos ampla. Pero o que un falante vernáculo do galego debe saber é que a normalización da lingua implica unha diversificación desta, e que xa non pode contentarse coa competencia adquirida espontaneamente na variedade vernácula correspondente, mais debe esforzarse por arrequentar o seu repertorio lingüístico ata conseguir o dominio da variedade común e polo menos unha familiaridade coa variedade exemplar. Inversamente, un aprendente de galego, e máis se vai usar profesionalmente a lingua, ten que saber que o dominio dos estilos formais do idioma é insuficiente; xa que unha competencia lingüística minimamente desenvolvida esixe posuír un abano de rexistros algo máis amplo: un bo aprendiz ten que aspirar a dominar a variedade común e familiarizarse con algunha variedade vernácula. Os falantes nativos non deben deixarse arrastrar por un nativismo inxenuo que lles vede o acceso ás variedades común e exemplar da lingua; os neofalantes teñen que esforzarse por alicerzar solidamente a súa competencia no idioma galego mediante a familiarización con modalides vernáculas.

14. Norma SubXectiva ou ideal de lingua. O Galego estándar, ENTRE O SUBESTÁNDAR E O SUPERESTÁNDAR

Algúns autores propoñen distinguir aínda outro tipo de norma, a que denominan norma subxectiva ou norma ideal, fundada nas actitudes e o sistema de valores en que estas se sustentan e que guían a avaliación subxectiva do desempeño lingüístico dos falantes ou a cualidade dos textos. O certo é que a norma, "qualquer que seja, não pode ser compreendida apenas como un conjunto de formas lingüísticas [variantes]; ela é também (e principalmente) um agregado de valores socioculturais articulados com aquelas formas" (Faraco 2002: 39), de feito, o que atopamos é "um complexo entrecruzamento de elementos léxico-gramaticais e outros tantos de natureza ideológica" que no seu conxunto definen as normas (Idem, 41; véxase tamén de Castilho 2002). A norma subxectiva non se confunde coa norma prescritiva, mais en todo caso pode dicirse que a segunda está fundada nun determinado ideal de lingua. Concretamente, en Galicia e en relación co idioma podemos distinguir tres grandes tipos de ideais de lingua, que se poden colocar nun continuum organizado nun eixo que vai da maior proximidade á maior distancia con respecto ao galego vernáculo: 
1) Ideais de lingua subestándar: refugan ou son reacios á constitución dun estándar galego, pois manteñen valores anti-prescritivistas e igualitaristas, e dirixen as súas lealdades máis cara ao local do que cara ao supralocal. O espontáneo, o auténtico e 'natural' valóranse moi por riba do controlado, o elaborado e 'artificial'. Podemos sinalar dúas correntes subestándar. Para unha, o ideal de lingua agóchase nos sociolectos urbanos (máis ben, dos barrios periféricos e as vilas grandes): é aí onde podemos atopar unha lingua viva, expresiva e innovadora. Para outros, tal ideal reside nos falares tradicionais, nos dialectos rurais ou semi-rurais, onde se aconchega o galego auténtico. Denominamos as respectivas actitudes (ou normas subxectivas) demótica e nativista: os bravús e os folquis, se se me permite a analoxía. Na corrente nativista conviven actitudes máis puristas, de defensa a ultranza do enxebrismo, con outras anti-puristas. Estas últimas son claramente dominantes na actitude demótica. Tanto esta coma o nativismo non purista móstranse claramente abertos aos castelanismos, polo que os seus ideais de lingua (especialmente da tendencia demótica) se aproximan ao interlectal.

2) Ideais de lingua estándar: propugan a construción dunha variedade central para o galego, un estándar autónomo e autocentrado (endonormativo). As lealdades diríxense máis cara á identidade colectiva galega (nacional) do que ás identidades parciais de grupo, en especial locais ou sociais. En xeral, predominan as actitudes igualitaristas, aínda que con intensidade variable: maior nos popularistas, máis atenuada nos cultistas. Como se acaba de ver, distinguimos dúas tendencias: unha máis popularista, partidaria dun estándar achegado ao galego vernáculo, e outra máis cultista, que postula un estándar máis orientado cara á lingua literaria. As actitudes con respecto ao prescritivismo van desde unha posición flexible (máis característica, pero non exclusiva, do popularismo) a outra máis ríxida (máis característica, pero tampouco exclusiva) do cultismo. Igualmente, a intensidade das actitudes puristas varía, aínda que a tendencia é similar ao que acabamos de dicir: o popularismo adoita ser menos purista, e o cultismo máis esixente neste terreo.

3) Ideais de lingua superestándar: propugnan a adopción dun estándar de orientación parcial ou totalmente exonormativa, adaptado do portugués ou identificado con este; notablemente afastado, por tanto, do galego vernáculo. Por vía da regra, son fortemente elitistas, puristas (contra os elementos non recoñecidos como lexítimos na norma lusitana) e prescritivistas. 


\begin{tabular}{lll}
\multicolumn{1}{l}{ CORRENTES/ TENDENCIAS } & \multicolumn{1}{c}{ IDEAL DE LINGUA } & \multicolumn{1}{c}{ DOMINIO EXISTENCIAL } \\
\hline A.1. demótica & galego (peri)urbano & falantes innovadores, \\
SUBESTÁNDAR & sociolectos urbanos & tradicionais, neofalantes \\
\cline { 2 - 3 } A.2. nativista & $\begin{array}{l}\text { galego tradicional } \\
\text { dialectos (rurais) }\end{array}$ & $\begin{array}{l}\text { falantes conservadores, } \\
\text { tradicionais }\end{array}$ \\
\hline B.1. popularista & estándar de base vernácula & falantes innovadores \\
ESTÁNDAR & galego común & tradicionais, neofalantes \\
\cline { 2 - 3 } B.2. cultista & estándar de base literaria & falantes innovadores, \\
& galego culto & tradicionais, neofalantes, \\
\hline C.1. reintegracionista & estándar elitista & neofalantes innovadores \\
SUPERESTÁNDAR & lusitanizado & \\
\cline { 2 - 3 } C.2. lusista & estándar portugués & neofalantes innovadores
\end{tabular}

Non me cabe dúbida de que, tanto historicamente coma na actualidade, a corrente central, maioritaria e que marcou as liñas básicas do proceso de estandarización do galego contemporáneo é a que aí denomino a do 'galego estándar' (Monteagudo 2003: 58-60). É certo que as outras correntes tiveron propugnadores e adherentes, algúns moi importantes, que deixaron a súa pegada na cultura lingüística do país e nos valores que conforman as distintas 'normas subxectivas' ou ideais de lingua. Esa pegada foi moito menor, endebén, no proceso de constitución do padrón e da norma culta, isto é, tanto da norma prescritiva coma da norma obxectiva do estándar. Aquela corrente central móvese entre dous polos, popularismo e cultismo, e a súa dinámica explícase fundamentalmente pola dialéctica entre estes. Como dixemos antes, na nosa opinión tanto as tendencias subestándar coma as superestándar conducen a un pozo cego: a primeira, ignorando a xustificación funcional do estándar, de feito bloquea o proceso de estandarización, a segunda, virada de costas á xustificación histórica da constitución dun estándar galego, conduciría a un divorcio insuperable entre as variedades vernácula e a culta, de consecuencias probablemente catastróficas para a pervivencia do idioma galego. Retomando unha terminoloxía que utilizamos antes, a primeira constitúe unha posición subóptima, a última unha superóptima, ambas inadecuadas.

O que aquí propugnamos, pois, como orientacións para o galego estándar é un prescritivismo funcional e ilustrado, que caracterizamos por catro trazos (elasticidade, relativismo, gradación e proporcionalidade) e un purismo racionalmente motivado. Un prescritivismo elástico, pois postula que as normas lingüísticas se ofrezan como orientacións para o comportamento lingüístico máis que imporse como ditames imperativos para o común dos falantes (cousa distinta é os falantes-modelo, coma os profesores, locutores, actores e personaxes públicos, con obrigas específicas e contextos de instrución 
formal). Relativista, pois proclama o valor pragmático e simbólico da diversidade da lingua, recoñece o valor de cada un dos estilos e variedades da lingua e asume o convencionalismo das variedades estandararizadas, ao tempo que admite que existen erros non só subóptimos, mais tamén superóptimos. A valorización das variedades vernáculas e dos estilos de comunicación informais implica que aparezan como tan inapropiadas variantes marcadamente informais en contextos formais como a inversa, variantes marcadamente formais en contextos informais. Prescritivismo graduado, pois sostén que as prescricións teñen máis forza e validez para certos estilos de comunicación que para outros, e incluso que carecen de xustificación para algúns. Prescritivismo proporcionado, pois defende que a esixencia de conformidade á normativa non deben ser as mesmas para todos os falantes e todas as situacións.

Canto ao purismo racionalmente motivado, xa Bartsch (2003: 40-41) argumentou a prol da xustificación dun certo conservadorismo lingüístico na variedade exemplar da lingua, en termos que non cómpre reiterar aquí. Fixemos invocación tamén da necesidade de defender o galego da presión poderosísima do castelán, que ameaza simplemente coa súa absorción e disolución. En definitiva, falando disto podemos evocar o dito aquel de que 'eu son nacionalista porque quero deixar de selo'. Non creo que o nacionalismo teña un contido trascendental, pero asúmoo como actitude defensiva ante unha ameaza que está a piques de aniquilar a nosa cultura, a nosa lingua e a nosa identidade colectiva. Igualmente, tanto o prescritivismo coma o diferencialismo purista en por si parécenme actitudes antipáticas, baleiras e irracionais, o que acontece é que o galego precisa desesperadamente un padrón lingüístico efectivo, orientado nun sentido diferencialista, para estabilizarse, desenvolverse e resistir a presión asimiladora do castelán. Hoxe por hoxe, son os dilemas con que nos enfrontamos, e neles temos que concentrarnos para podelo superar. Confío en que, discorrendo, falando e construíndo entre todos e todas saberemos conseguilo.

\section{REFERENCIAS BIBLIOGRÁFICAS}

Álvarez Cáccamo, C. (1989): "Variaçom lingüística e o factor social na Galiza”, Hispanic Linguistics 2.2, 253-98.

Álvarez Cáccamo, C. (1998): "From 'switching code' to 'code switching': Towards a reconceptualisation of communicative codes", en P. Auer (ed.), Code Switching in Conversation. Language, interaction and identity. London / New York: Routledge, 29-48.

Álvarez Cáccamo, C. / Herrero Valeiro, P. (1996): "O continuum da escrita na Galiza: entre o espanhol e o português", Agália 46, 143-56. 
Bagno, M. (ed.) (2002): Lingüística da norma. São Paulo: Loyola.

Bagno, M. (2003): A norma oculta. Lingua E poder na sociedade brasileira. São Paulo: Parábola.

Bartsch, R. (1987): Norms of Language. Theoretical and Practical Aspects. London / New York: Longman.

Bartsch, R. (2003): "Estandarización e cultivo das linguas: Posibilidades, límites e xustificación”, Grial 160, 30-41.

Bernstein, B. (1971/1973/1975): Classes, codes and control. London, Routledge and Kegan Paul.

Berruto, G. (1980): La variabilità sociale della lingua. Torino: Loescher.

Berruto, G. (1995): Fondamenti di sociolinguistica. Roma / Bari: Laterza.

Berruto, G. (2004): Prima lezioni di sociolinguistica. Roma/ Bari: Lareza.

Biber, D. (1988), Variation across speech and writing. Cambridge: Cambridge University Press.

Biber, D. (1994): "An Analytical Framework for Register Studies”, en D. Biber \& E. Finegan (eds.): Sociolinguistic Perspectives on Register. New York/ Oxford: Oxford University Pres, 31-56.

Biber, D. (1995): Dimensions of Register Variation. A cross-linguistic comparison. Cambridge: Cambridge University Press.

Brown, P. / Fraser, C. (1979): "Speech as a marker of situation", en K. R. Scherer / H. Giles (eds.), Social markers in speech. Cambridge: Cambridge University Press, 33-108.

Carballeira Anllo, X. M. / González Lorenzo, M. / Iglesias Sierra, P. / Lameiras Fernández, M. (1994): "Actitudes e usos da poboación ourensá de ensino medio”, en R. Lorenzo (ed.), Actas do XIX Congreso Internacional de Lingüistica e Filoloxía Románicas. Volume VI. Sección VI. Galego. Sección VIII. Romania nova. A Coruña, Fundación 'Pedro Barrié de la Maza, Conde de Fenosa', 17-27.

Casares Berg, H. / Fernández Salgado, X. A. / Loredo Gutiérrez, X. / Suárez Fernández, I. (2003): "Actitudes lingüísticas en Galicia”, Grial 160, 52-59.

Casares Berg, H. et alii (2003): O galego segundo a mocidade. Unha achega ás actitudes e discursos sociais baseada en técnicas experimentais e cualitativas. A Coruña: Real Academia Galega- Seminario de Sociolingüística.

Castillo, A. Teixeira de (2002): "Variação dialetal e ensino institucionalizado da língua portuguesa", en M. Bagno (ed.), 27-36.

Cidrás Escáneo, F. (1994): "Modelos de lingua e variación sintáctica", Cadernos de Lingua 10, 103-118.

Coseriu, E. (1981 a): "La lengua funcional" en E. Coseriu, Lecciones de lingüistica general. Madrid: Gredos, 287-315. 
Coseriu, E. (1981b): "Los conceptos de 'dialecto', 'nivel' y 'estilo de lengua' y el sentido propio de la dialectología”, Lingüística Española Actual 3, 1-32.

Coulmas, F. (1989): "Democracy and the crisis of normative linguistics", en F. Coulmas (ed.), Language Adaptation. Cambridge: Cambridge University Press, 177-193.

Coulmas, F. (1996): "Introduction" en F. Coulmas (ed.), The Handbook of Sociolinguistics. Oxford: Blackwell Publishers,1-11.

Daneš, F. (1987): "Values and Attitudes in Language Standardization", en J. Chloupek, J. Nekvapil et alii, Reader in Czech Sociolinguistics. Amsterdam/ Philadelphia: John Benjamin, 206-45.

Dubert, F. (2002): "Os sociolectos galegos", Cadernos de lingua 24, 5-27.

Faraco, C. A. (2002): "Norma-padrão brasileira: desembaraçando alguns nós”, en M. Bagno (ed.), 37-61.

Ferguson, Ch. A. (1994): "Dialect, Register, and Genre: Working Assumptions About Conventionalization", en D. Biber \& E. Finegan (eds.): Sociolinguistic Perspectives on Register. New York/ Oxford: Oxford University Pres, 15-30.

Giles, H. / Coupland, N. (1991): Language: Contexts and Consequences. Buckingham: Open University Press.

Halliday, M. A. K. (1978): Language as Social Semiotic. The Social Interpretation of Language and Meaning. London: Edward Arnold Publishers.

Halliday, M. A. K. (1990), Spoken and Written Language. Oxford: Oxford University Press.

Hudson, R. A. (1996² [1980]): Sociolinguistics. Cambridge: Cambridge University Press.

Jollin-Bertocchi, S. (2003): Les niveaux de langage. Paris: Hachette.

Kabatek, Johannes (1991): "Interferencias entre galego e castelán: problemas do galego estándar”, Cadernos de Lingua 4, 39-48.

Kabatek, Johannes (1994): "Galego escrito e lingua común na segunda metade do século XX", Grial 122, 157-179.

Kabatek, Johannes (1996): Die Sprecher als Linguisten. Interferenz- und Sprachwandelphänomene dargestellt am Galicischen Gegenwart, Tübingen, Max Niemeyer. [Trad. ao galego, Os falantes como lingüistas. Tradición, innovación e interferencias no galego actual. Vigo: Xerais, 2000.]

Kabatek, Johannes (1997 a): "Strengthening identity, differentation and change in contemporary Galician", en Cheshire, Jenny \& Stein, Dieter (eds.), Taming the Vernacular. From Dialect to Written Standard Language, London/ New York: Longman, 185-199.

Kabatek, Johannes (1997 b): "The Koineization Process of Contemporary Galician as a Field for the Study of Language Change”, en Fernández Salgado, Benigno (ed.), Proceedings of the $4^{\text {th }}$ International Conference on 
Galician Studies /Actas do IV Congreso Internacional de Estudios Galegos, 2 vols., Oxford: Centre for Galician Studies, vol. I, pp. 163-178.

Labov, W. (1983): Modelos sociolingüisticos. Madrid: Cátedra.

Lamuela, X. / Monteagudo, H. (1996): "Planificación lingüística”, en M. Fernández Pérez (coord.), Avances en... Lingüística Aplicada. Santiago: Universidade de Santiago de Compostela, 229-301.

Leckie-Tarry, H. (1995): Language \& Context. A functional linguistic theory of register. London / New York: Pinter.

LePage, R. \& Tabouret-Keller, A. (1985): Acts of Identity. Creole-based approaches to language and ethnicity. Cambridge, Cambridge University Press.

LePage, R. 1989: "What is a language?", York Papers in Linguistics 13, 9-24.

LePage, R. B. (1996): "The Evolution of a Sociolinguistic Theory of Language", en F. Coulmas (ed.), The Handbook of Sociolinguistics. Oxford: Blackwell Publishers, 15-32.

López del Castillo, Ll. (1984 [1976]): Llengua standard i nivells de llenguatge. Barcelona: Laia.

López García, Á. (1996): "Teoría de catástrofes y variación lingüística”, Revista de la Sociedad Española de Lingüística 26.1, 15-43.

López García, Á. (2000): Cómo surgió el español. Madrid, Gredos.

Lucchesi, D. (2002): "Norma lingüística e realidade social", en M. Bagno (ed.), 63-92.

Milroy, J. / Milroy, L. (1985): Authority in Language. Investigating Language Prescription and Standardisation. London / New York: Routledge and Kegan Paul.

Milroy, J. \& Milroy, L. (1997): "Varieties and Variation", en F. Coulmas (ed.), The Handbook of Sociolinguistics. Blacwell, Oxford, 47-64.

Monteagudo, H. (1994): "Aspectos da teoría da lingua estándar do Círculo Lingüístico de Praga e os seus continuadores", Grial 122, 141-55.

Monteagudo, H. (1997): "Modelos de lingua. Consideracións teóricas ó fío do debate sobre a estandarización do galego", Cadernos de lingua 16, 5-33.

Monteagudo, H. (1998): Historia social da lingua galega. Vigo, Galaxia.

Monteagudo, H. (2002): "Presentación", en H. Monteagudo / X. M. Bouzada (eds.), O proceso de normalización do idioma galego (1980-2000). Volume I. Política lingüistica. Análise e perspectivas. Santiago: Consello da Cultura Galega, 9-28.

Monteagudo, H. (2003): "A demanda da norma. Avances, problemas e perspectivas no proceso de estandarización do idioma galego", en H. Monteagudo / X. M. Bouzada (eds.), O proceso de normalización do idioma galego (1980-2000). Volume III. Elaboración e difusión da lingua. Santiago: Consello da Cultura Galega, 37-129.

Ong, W. J. (2002): Orality and Literacy. London / New York: Routledge. 
R.A.G. (1995): Usos lingüísticos en Galicia. Compendio do volume II do Mapa Sociolingüístico de Galicia. S.l.: Real Academia Galega- Seminario de Sociolingüística.

Regueira, Xosé Luís (1994): "Modelos fonéticos e autenticidade lingüística", en Cadernos de Lingua 10, 37-60.

Regueira, Xosé Luís (1997): "Elementos para a definición dun modelo fonético estándar da lingua galega”, en Fernández Salgado, Benigno (ed.), Proceedings of the $4^{\text {th }}$ International Conference on Galician Studies /Actas do IV Congreso Internacional de Estudios Galegos, 2 vols., Oxford: Centre for Galician Studies, vol. I, 179-194.

Regueira, Xosé Luís (1999): "Estándar oral e variación social da lingua galega”, en Álvarez, Rosario \& Vilavedra, Dolores (eds.), Cinguidos por unha arela común, 2 vols., Santiago: Universidade de Santiago de Compostela, vol. I, 855-875.

Regueira, Xosé Luís (2002): "A sílaba en galego: lingua, estándar e ideoloxía”, en Lorenzo, Ramón (coord.), Homenaxe a Fernando R. Tato Plaza, Santiago: Universidade de Santiago de Compostela, 235-254.

Schiffman, H. (1996): Linguistic Culture and Language Policy. London / New York: Routledge.

Trudgill, P. (1982 [1974]): Sociolinguistics. An Introduction to Language and Society. London: Penguin.

Trudgill, P. (1983): On Dialect. Social and Geographical Perspectives. New York / London: New York University Press.

Ure, J. (1982): "Introduction: approaches to the study of register range", International Journal of the Sociology of Language 35, 1-23.

Veiga, R. (2004): "A lingua do noso audiovisual", en Libro branco da cinematografía e artes visuais en Galicia. Santiago, Consello da Cultura Galega, 311-30.

Vidal Figueroa, T. (1997): "Estructuras fonéticas de tres dialectos de Vigo", Verba 24, 313-332. 